\title{
Ahmadinejad, Iran and Foreign Policy Dysfunction in Tajikistan
}

\author{
Brenton Clark*
}

Throughout the presidency of Mahmoud Ahmadinejad, Tajikistan became, on the surface at least, an increasingly important political partner to Iran. Tajikistan according to Ahmadinejad was a "strategic partner" and in fact the two states' "common history and culture" made them inseparable. Ahmadinejad's emphasis on Tajikistan within Iran's broader foreign policy led to considerable discussion among regional observers and analysts who declared that the relationship between Iran and Tajikistan could potentially develop into a so-called "Persian alliance," which could then der the regional political balance. However, lying just below the surface of relatilubetween Iran and Tajikistan was a disjuncture between rhetoric and reality. This article argues that despite the public amity that existed between the two states, strong and substantive Iran-Tajik relations were not achieved by the close of Ahmadinejad's presidency. This was due in part to a dysfunctional Iranian foreign policy approach, which often led to the mismanagement of this interstate relationship. This factor along with the unwillingness of Tajik elites to go from words to deeds and the broader impact of sanctions, international isolation, and regional rivalry, meant that Iran was largely unable to fulfill its prominent political and economic objectives in Tajikistan.

Key words: Ahmadinejad, Central Asia, foreign policy, Iran, Tajikistan

\section{Introduction}

$\mathrm{T}$ he presidential election victory of Mahmoud Ahmadinejad in 2005 heralded a sea change in the politics of Iran. Ahmadinejad's populist, nationalist rhetoric, and confrontational stance on a range of political issues indicated that a major shift was about to take place in how Iran conducted itself on the international stage. Ahmadinejad's often antagonistic approach to international relations while bringing about a much more assertive Iranian foreign policy position, also instituted a pattern of crisis that would see the imposition of further economic sanctions and increased international

*Brenton Clark is a PhD Candidate at the Centre for Arab and Islamic Studies (the Middle East and Central Asia) at the Australian National University. Between January and May 2013, he conducted extensive field research in Iran and Tajikistan. 
isolation. Rather than providing the Iranian people with a grand and prosperous future, Ahmadinejad brought only further economic hardship domestically, and an erosion of Iran's strategic and political position internationally (Habibi, 2013, pp. 1-8).

Iran's relations with Tajikistan during this period cannot be removed from this pattern of crisis and international tension in Iran's foreign relations. Iran's growing isolation on the international stage and its increasingly hostile relationship with the West had an immense impact on the trajectory of Iran's relations with Tajikistan. Both out of necessity in the face of ever mounting sanctions and international isolation stemming from the West, and out of choice due to Ahmadinejad's emphasis on "Looking East" to fulfill Iran's foreign policy agenda, Tajikistan became, on the surface at least, an increasingly important political partner to Iran (Vakil, 2006, pp. 51-65). Ahmadinejad devoted significant attention to building relations with Tajikistan. Tajikistan according to Ahmadinejad was a "strategic partner," and in fact, the two states' "common history and culture" made them inseparable (Sodiqov, 2011a, p. 19). Backing this rhetorical flourish, Ahmadinejad made a special effort to ensure that Tajikistan would be front and center of his regional foreign policy approach, visiting the country and meeting its president Emomalii Rahmon on an almost annual basis. ${ }^{1}$ Ahmadinejad's efforts toward Tajikistan led to considerable discussion among regional observers and analysts who declared that the relationship between Iran and Tajikistan could potentially develop into a so-called "Persian alliance," which could reorder the regional political balance (Francois, 2010). However, lying just below the surface of relations between Iran and Tajikistan was an incredible disjuncture between rhetoric and reality.

This article argues that despite the public amity that existed between the two states throughout Ahmadinejad's presidency, strong and substantive Iran-Tajik relations were not achieved due in part to a dysfunctional Iranian foreign policy approach, which often led to the mismanagement of this interstate relationship. This factor along with the unwillingness of Tajik elites to go from words to deeds and the broader impact of sanctions, international isolation, and regional rivalry meant that Iran was largely unable to fulfill its prominent political and economic objectives in Tajikistan.

\section{A Brief History of Iranian Engagement in Post-Soviet Tajikistan}

The fall of the Soviet Union in late 1991 brought excited hope within Iran's political establishment that close political, economic. and cultural links could be established with the five post-Soviet republics. (1) particular, the Iranian government focused much of its attention toward Tajikistan, which was viewed by many within the Iranian government as a "Persian" state that would naturally gravitate to Iran on account of thousands of years of $b$.ed linguistic, cultural, and societal relations (Atkin, 2013, pp. 361-376). Despite Tajikistan lacking the economic and political weight of other newly independent post-Soviet Central Asian republics such as Turkmenistan and Kazakhstan, Iranian foreign $£$ ials enthusiastically proposed a range of cultural, economic, and political programs that would reconnect Tajikistan with Iran 
after the so-called 70-year "disruption" of relations caused by Soviet rule ("Iran's Maleki", 1992). As aptly summed up by Djalili and Grare, although Tajikistan was geographically and politically "remote," Iran was "very sensitive to everything that had to do with Tajikistan, because of the cultural, historic and above all linguistic affinities" that were perceived to have existed between these two societies (Djalili \& Grare, 1998, p. 127). Within days of independence, the Tajik government received a number of Iranian political and economic proposals that ranged from the establishment of Persian language schools and facilities, regular air links between Iranian cities and Dushanbe, the building of highways which would eventually connect Iran's eastern provinces to Tajikistan, and the establishment of commercial deals with Iranian private enterprises seeking new markets and new opportunities. These efforts to "re-establish" ties between Iran and Tajikistan were according to Iran's Deputy Foreign Minister of the time, Abbas Maleki, a "natural continuation" of the common history that existed between the two states ("Iran's Maleki," 1992).

However, the great hopes for a close partnership between Iran and Tajikistan were dashed by the serious instability that wracked Tajikistan in the months leading up to and following independence. Worsening economic conditions in Tajikistan, increased freedom of expression brought about by Soviet central reforms, and poor governance had contributed to a political environment whereby multiple groups and actors jockeyed for power over the crumbling Tajik state. Throughout the second half of 1991, protesters filled the streets of Tajikistan's capital Dushanbe as opposition groups of various ideological and regional stripes sought to challenge central So control in the country. By May 1992, Tajikistan had plunged into civil 2 between those who supported the Communist political status quo and a fractious opposition made up of regional and local groups, Islamicts, and democrats. ${ }^{2}$ The opposition briefly took control of the Tajik capital 1992 had been pushed back by the combined weight of pro-Communist forces supported by Russia and Uzbekistan.

The defeat of the opposition and the rise to power of Emomalii Rahmon seriously undermined Iran's relationship with Tajikistan. Iran was frequently accused by the Tajik government of supporting the opposition groups, in particular the Islamic Renaissance Party (IRP). Indeed, such accusations were well-founded. Iran had provided financial and material support to not only the IRP, but also a number of other opposition groups who had briefly taken control of the Tajik capital. However, as highlighted by Mesbahi, Iran's "overall policy" toward the opposition and in particular its support of the most prominent opposition group - the IRP -, CD ild be "characterized as skeptical optimism, reflecting skepticism in practice and substance and optimism in the realm of possibilities" (Mesbahi, 1994, p. 126). According to Mesbahi (1994), Iran's support of the IRP in particular was "hesitant if not passive" and this hesitation was a reflection of Iran's awareness that the "clash in Tajikistan, as elsewhere in Central Asia, while couched in ideological terms, reflected tribal, regional, and ethnic differen rather than an immediate receptivity to an Islamic alternative" (p. 126). Nough a number of IRP figures had declared their intention to establish an "Islamic State," 
Iranian elites were well aware of the ideological fissures that existed between their own Shi'a Islamic revolution and the Sunni inspired ideology of the IRP. ${ }^{3}$ Furthermore they felt that the group was "unready" to pursue such an agenda and was using Islam in the service of a very narrow, subregionalist set of goals. ${ }^{4}$

Alongside this acknowledgment of the ideological weaknesses that existed within the IRP, Iran viewed maintaining friendly relations with Russia as the ultimate priority when dealing with Tajikistan and Central Asia. Iran was always hesitant to provide too much support to the opposition in the face of its much more important relations with Russia, who continued to act as the Tajik government's political and security guarantor. This "Russo-centrism" in Iranian foreign policy was an acknowledgment of Russia's historical interests in Tajikistan and the wider region (Mesbahi, 1994, p. 128). Furthermore, Iranian policy planners feared that a strong attempt to increase their state's influence in Tajikistan by overtly supporting the opposition groups, particularly the IRP, would antagonize Russia's political leadership who could quite easily shut the door on cooperation in other facets of the two states' relations (Freedman, 2000, p. 69). In particular, Russian arms sales and support for Iran's nuclear program were seen as a top priority that could not be sacrificed for the sake of supporting a ragtag opposition, in the somewhat politically and geographically peripheral Tajikistan. ${ }^{5}$ Support for the opposition would therefore engender a difficult balancing act for Tehran. For instance, if Iran provided too much support to the opposition, or openly and aggressively undermined Tajikistan's new regime, Tehran's substantive links with Moscow, which had already been placed in jeopardy in the preceding months due to Iran's support of the opposition, could be permanently damaged, thus impacting Iran's broader regional position. However, if Iran did not provide enough support to the opposition it would be pilloried at home, and have its legitimacy as the center for worldwide Islamic activism increasingly questioned, something that had already occurred with the radical press attacking Rafsanjani and the foreign ministry' Pnishandling" and lack of support given to the opposition in Tajikistan.

Nevertheless, the opposition by the end of 1992 was in tatters. With the conflict heading toward a virtual stalemate, the Iranian government under the leadership of Apar Hashemi Rafsanjani sought to work closely with the Russian governmerr in putting an end to the conflict in Tajikistan. Iranian officials based in Tajikistan, Afghanistan, and Iran applied significant pressure on opposition figures to negotiate and compromise with the Rahmon government and after a number of fitful starts, nine rounds of peace negotiations took place over three years between the opposition and the Tajik government, with both sides signing a power-sharing arrangement in 1997 (Iji, 2001). Iran sought to play a central role in the mediation process and remained a patron to the Tajik opposition throughout these negotiations. Iran's consistent efforts to both encourage and cajole the opposition into engaging in peace talks with the Rahmon government earned the country considerable praise. However, question marks remained over Iran's conduct in the violent events that led to the civil war in Tajikistan. A number of Tajik government figures believed that Iran's encouragement and support for the 
opposition had led to the outbreak of violence in the country and had prolonged the hostilities. ${ }^{7}$ Although this view remains prevalent in certain segments of Tajikistan's political elite, Iran's support for the opposition should not be overstated and cannot be considered to have been at a level that could have drastically changed the events and outcomes of the civil war in Tajikistan, a conflict whose basis lay almost entirely in the regional and local tensions that existed within Tajikistan at the time of the Soviet collapse.

While Iran had played a major political role in Tajikistan during the civil war, and was particularly influential with the Tajik opposition, broader ties between the two states remained limited. For instance, (in)1997 Iranian-Tajik trade ties stood at USD 32 million, with Iran's share of 'Iaj1kistan's total trade turnover constituting just 7\% (United Nations Comtrade, 2014). Furthermore, beyond the fields of economics and trade, other measures of Iran's interactions with Tajik society also remained low. For instance, very few Tajiks undertook study in Iranian higher education institutions; the early Iranian encouragement for Tajiks to take up the Arabic script in place of Cyrillic had fallen by the wayside, and air routes between the two countries were patchy and irregular. ${ }^{8}$ The low level of ties between the two states was of course not surprising. Throughout the civil war period it was almost impossible for Iran to deal with Tajikistan in what could be considered a "normal political setting" and in light of the problematic circumstances within Tajik domestic society, the very minor outcomes of Iran's engagement were, if anything, commendabl

With the ena of the Tajik Civil War coinciding with the election of a new Iranian president, Mohammed Khatami (1997-2005), there was renewed hope that Iran's relations with Tajikistan would finally reach their full potential. However, Tajikistan and the wider Central Asian region rarely rated a mention within Khatami's broader foreign policy approach (Dunn, 1997, p. 27; Robin, 1997, p. 7). Instead, Khatami declared that the centerpiece of his foreign policy would be an effort to seek détente with the United States and the "West," based on a number of normative themes, the most prominent of which was an effort to engage in an apparent "Dialogue of Civilizations." 9 Unfortunately, while Khatami pursued his lofty internationalist agenda, Tajikistan with its weakened economy and fragile post-civil war political and security situation was a secondary element within Iran's foreign policy.

This political neglect of Tajikistan would come to an abrupt end, however, following the geopolitical shift brought about by the attacks of September 11, 2001 (9/11). 9/11 highlighted the potential for Tajikistan to become a strategically and politically significant actor in the U.S. efforts to rid neighboring Afghanistan of the Taliban and Al-Qaeda. Tajikistan's President Rahmon rushed to declare that Tajikistan was "in solidarity with the United States people" ("Tajikistan to Cooperate With U.S.," 2001). By the close of 2001, Tajikistan had provided airfields for U.S. and North Atlantic Treaty Organization (NATO) operations in Afghanistan, overflight rights for American military aircraft, and had even broached the possibility of the permanent stationing of U.S. troops in the country (Jonson, 2006, p. 58). As a reward for Tajikistan's loyalty in the "War on Terror", the country received substantial economic aid and security assistance. For instance, the United States increased its aid 
budget significantly from 72 million USD in 2001 to 162 million USD in 2002 (Bureau of European and Eurasian Affairs, 2002, 2003). Furthermore, the U.S. newfound presence in Tajikistan also paved the way for the country's accession into NATO's Partnership for Peace program and the development of close military collaboration between the two countries' militaries (North Atlantic Treaty Organization, 2002).

Tajikistan sought to use this new American interest to exact much needed economic rents, while lowering, yet maintaining Russia's ongoing influence and interest in the country. ${ }^{10}$ Furthermore, the Tajik leadership recognized early on that cooperation with the United States could not only reshape what up to that point had been an imbalanced and overwhelmingly dependent relationship with Russia, but could also provide it with the leverage necessary to "implement a policy of reaching out to the world...pursuing a kind of multivector policy, which it had previously been unable to pursue" (Jonson, 2006, p. 59). Using and building upon its newfound importance to the United States and the West, Rahmon elucidated a foreign policy approach which would be based on an "open-door policy," whereby Tajikistan would cooperate with any state who was willing to cooperate with it, above all in the field of economics. Tajikistan was mindful that diversifying its relations with as many international partners as possible would ensure its stability and provide it much needed breathing room in its international affairs (Jonson, 2006).

This newfound Tajik confidence and assertiveness on the international stage, along with the presence of Iran's major political rival the United States within Tajikistan and the wider region, initially acted as a lightning rod for Iranian-Tajik relations in the post-9/11 period. Prior to 9/11, Iran could afford to pay only a cursory glance to a poorer cousin, which lacked substantial strategic, economic, and political weight. However, with the United States-Iran's main political rival-seeking to influence the political trajectory of Tajikistan, a drastic reinvigoration of Iranian foreign policy would be required.

In attempting to build Iran's influence in the post-9/11 period, Khatami placed a particular focus on economic diplomacy, providing funding for large-scale infrastructure projects such as the construction of the five-km long Anzob tunnel, which would link Dushanbe through the Hissar Ranges to the northern region of Sughd (formerly Khojand). The Khatami government had pledged to provide USD 31.2 million of the estimated USD 110 million cost of the project, consisting of USD 10 million as a grant, and USD 21.2 million as a loan (Sanaei, 2011, p. 191). Constructing the tunnel was viewed by the Tajik government as a major economic and strategic priority. For a large portion of the year, Tajikistan was geographically split in two due to winter snowfalls, avalanches, and the decision by the Uzbek government to unilaterally close road and rail lines connecting Tajikistan with its northern province. ${ }^{11}$

The most prominent infrastructure project that Iran committed to, however, was the construction of the Sangtuda 2 hydroelectric station. The Sangtuda hydroelectric project initially began construction during the 1980s and was originally envisaged to consist of two hydroelectric power plants, Sangtuda 1, which would have an energy output of $671 \mathrm{MW}$ and the smaller Sangtuda 2 with a 
capacity of 220 MW (Tajikistan Ministry of Foreign Affairs, 2011, pp. 4-5). However, due to financing issues and the chaos wrought by the civil war, the project remained unfinished throughout the 1990s. As a consequence, Tajikistan's electricity production sat well below domestic consumption levels throughout the postindependence $2 \mathrm{~d}$, with large swathes of the country suffering from frequent blackouts and limited daily supplies of electricity, serving as a major drag on the country's continued economic development. Iran's willingness to invest in large-scale infrastructure projects in Tajikistan marked not only a qualitative but also a quantitative improvement in the two states' economic engagement. From the close of 2001-2005 total trade between Iran and Tajikistan increased from a lowly USD 36.95 million to a respectable USD 104.7 million, with Iran becoming Tajikistan's fourth largest import partner (Observatory of Economic Complexity, 2014).

Although Iran had managed to increase its economic presence, there still remained a long way to go before Iran could be considered a prominent political and security actor in Tajikistan. Indeed Iran's focus on economic diplomacy in Tajikistan had led to a much greater and well developed level of interstate dialogue and interaction between the two states' political elites, which was evidenced by the many meetings and summits held between the two states following 9/11. Overall, however Tajikistan remained largely peripheral to Iran in its wider foreign policy stance, particularly when considered in light of Afghanistan where Iran had committed hundreds of millions of dollars in aid and had actively attempted to undermine the U.S. military and political presence. ${ }^{12}$ Furthermore, Iran continued its deference to Moscow when it came to Tajikistan, unquestionably supporting Russia's position as the key security guarantor of Tajikistan, and was almost never willing to challenge Russia's central political role in the country (Smith, 2002, p. 1). Iran also displayed a reluctance to fully back Tajikistan in its ongoing disputes with Uzbekistan, despite the fact that Uzbekistan had thrown its full support behind the U.S. "War on Terror" and had not only placed Tajikistan in a geopolitical bind by blocking most trade routes into the country, but had also endorsed American containment policies

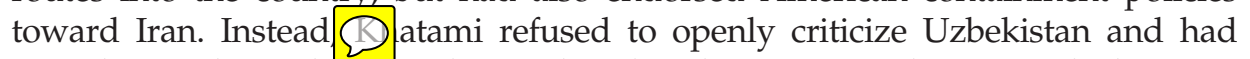
actively sought to deverop close political and economic relations with the Karimov regime ("Uzbek and Iranian Presidents," 2002).

A number of Iranian elites were highly critical of Khatami's lack of engagement in Tajikistan and the wider Central Asian region, particularly in the years leading up to 9/11. For instance, prominent Iranian academician Farhad Atai declared that there was an "absence of modern ideas and innovative thinking in the execution of Iran's policies in the region" (Atai, 2000, p. 119). Meanwhile, in 2001, Iranian parliamentarian and Central Asian expert, Elaleh Koolaee felt that Iran's policies in Central Asia were:

Perhaps one of the most vivid pieces of evidence of the failure of the foreign policy of the Islamic Republic of Iran ....we have not been able to take sound advantage of the opportunities created...the significance of the region was not properly appreciated despite the attention we emphatically underlined in our approach towards our northern borders in recent years. (quoted in Athary, 2001, p. 4) 
Although Iran had made significant headway in Tajikistan by contributing to the country's much needed economic revitalization, overall Iran's inattentiveness had left it as a secondary player that had not fulfilled its political potential in a region it apparently felt "preeminently a part of" (Maleki, 2007, p. 176).

\section{A New President and a New Approach in Tajikistan?}

The presidential election victory of Ahmadinejad in 2005 heralded what could be considered a major shift in Iranian foreign policy. Khatami's eightyear struggle to bring about rapprochement with the West and his efforts to improve Iran's international image had largely come to naught. Abandoning what he considered to be an exercise in futility, Iran's new president pursued with vigor a foreign policy approach that focused heavily on defending Iran's right to develop a nuclear program, and which gave much greater attention to building relations with Iran's eastern neighbors and the "anti-imperialist" global south. In the eyes of Ahmadinejad, no longer was Iran willing to sacrifice its national interests in the pursuit of better relations with the West, and countering Washington-led containment efforts became an "objective for Tehran in its own right" (Maleki, 2007, p. 170). Irar@ policy planners sought to find new ways to frustrate the U.S. agendas, 2ru solidify and expand their country's influence and interests both regionally and internationally.

A key aspect of these efforts was improving Iran's bilateral ties with the Central Asian republics, while also solidifying Iran's already extensive cooperation with India, China, and Russia. Iranian policy planners believed that developing positive relations with its Eastern neighbors could allow their country to circumvent growing American economic and political pressure, provide significant economic benefits, and could also eventually lead to the creation of a countervailing bloc of states, which would undermine and bring to an end American unipolarity (Dorraj \& Entessar, 2013). ${ }^{13}$ Although these ideas were not new and preceded Ahmadinejad's presidency, it can be argued that throughout his two terms in office, Ahmadinejad sought to recenter Iran's foreign policy from focusing much of its attention toward the West, to engaging much more actively with the East (Dorraj \& Entessar, 2013). Ahmadinejad's prominent and frequent visits to the Central Asian republics and his consistent efforts to gain full member status within regional institutions such as the Shanghai Cooperation Organization attest to the increased importance placed on the region during his presidency (Peyrouse \& Ibraimov, 2010). Furthermore, Iran's increasingly close ties with China also placed Central Asia in a much more prominent position within its foreign policy thinking (Mackenzie, 2010). Both Iran and China proposed the development of a series of roads, rail lines, and gas and oil pipelines, which would criss-cross Central Asia, thus requiring a much greater Iranian focus upon its Central Asian neighbors.

This attention on the East became an even greater necessity as Ahmadinejad's bellicose rhetoric and conflictual stance toward Israel, and aggressive defense of Iran's nuclear program created an ever growing international consensus that Iran had to be punished for its apparent intransigence. The regime 
of sanctions upon Iran grew increasingly suffocating into Ahmadinejad's second term and by 2012 Iran had become largely isolated from the international banking system, making it almost impossible for Iran to sell its oil and receive direct foreign investment in a financially interlinked world ("The Lengthening List," 2013). The severe sanctions regime had a crippling impact upon an already weakened Iranian economy and further underscored the vital need for Iran to diversify its international partners (Cordesman, Bosserman, \& Khazai, 2012; "Q\&A: Iran Sanctions," 2013).

The impact of sanctions on Iran's economy was acknowledged by President Ahmadinejad who declared in 2012, that the cumulative weight of unilateral American and international sanctions amounted to "the heaviest economic onslaught on a nation in history... everyday all our banking and trade activities and our agreements are being monitored and blocked" (Zakaria, 2012). It was in this context of increasingly severe political and economic isolation that Ahmadinejad sought to forge a close relationship with Tajikistan. However, as will be shown, this relationship would be held hostage to international and regional events, as well as Iran's inability to fulfill its ambitious economic, political, and cultural agendas.

\section{Ahmadinejad Comes to Dushanbe}

Ahmadinejad made his first state visit to Tajikistan in July 2006 for a meeting with his Afghan and Tajik presidential counterparts. During the visit Ahmadinejad promulgated a range of Iranian investment projects and initiatives, and notably promised substantial Iranian assistance to its so-called "close cultural cousin," Tajikistan. This first visit to Tajikistan by Ahmadinejad would not only be an instructive example of the Iranian president's approach to Tajikistan but also of the inherent challenges faced in wider Iranian-Tajik relations.

Arriving in Dushanbe to a rousing public reception, Ahmadinejad inaugurated the opening of the Anzob tunnel, a project which had originally been launched by his predecessor, Khatami. Poor workmanship by the Iranian state-owned company Sobir had plagued construction of the tunnel since 2003 and had led Tajik locals to nickname Anzob, "the tunnel of death" due to its almost nonexistent ventilation and lighting, alongside its poorly maintained road surface that was often waterlogged and badly potholed due to groundwater that would flood from the tunnel's crudely sealed walls. ${ }^{14}$ Many Tajik experts interviewed by the author blamed both governments for what one scholar claimed to be a "nightmare" in the building of Anzob, that at the time of writing still has not been completed. However, much of the fault was laid squarely at Iran, which was seen to have mismanaged the project and had not carried through with its political and economic promises. Nevertheless despite these criticisms (which were repeated by a number of other Tajik experts), the opening of Anzob was rushed ahead to provide Ahmadinejad with the public relations boon he so often desired. Casting aside, or at least ignoring, the unfinished and poorly constructed nature of the tunnel, Ahmadinejad bathed in the glow of this Iranian engineering achievement, boasting in front of a crowd of Tajiks Iran's role in securing their future independence 
and sovereignty by constructing a tunnel, which would vitally connect Dushanbe to its northern regions. Furthermore, Ahmadinejad blithely declared to the Tajik crowd, "I look at you and I see Iranians" and that "the tears of happiness I see in your eyes are our happiness too" and highlighted his wish to see closer relations develop between the peoples of the two states (Golovina, 2006).

Following the opening of the Anzob tunnel Ahmadinejad proceeded to undertake discussions with Tajik president Rahmon who he had previously met in Tehran in January of the same year. According to a number of the U.S. diplomatic cables, which were released by WikiLeaks in 2010, senior Tajik officials expressed significant discomfort and worries toward Ahmadinejad's visit to Dushanbe. In private discussions with U.S. diplomatic officials, and with the U.S. Ambassador to Tajikistan, Richard Hoagland, the Director of the of the Tajik President's Strategic Research Centre, Suhrob Sharipov acknowledged that Tajikistan did not wish to have its international reputation sullied by politically engaging too closely with Iran. However, Sharipov also noted that Tajikistan desperately required foreign investment, and therefore, welcomed Iranian economic assistance (Hoagland, 2006e). Such a stance was also confirmed by Tajik Foreign Minister Talbak Nazarov who bluntly surmised that it did not matter which country invested in Tajikistan as "all money smells the same," alluding to the fact that the country had to take what it could get (Hoagland, 2006c). In a discussion with Hoagland only days before Ahmadinejad's arrival, Nazarov continued his somewhat blunt, yet pragmatic assessment of international relations. Speaking openly and frankly about Iran, Nazarov claimed his government had "no special love" for Iran, and simply required its economic assistance above all else. Furthermore, Nazarov also highlighted his fear that Ahmadinejad would make the visit "overly political" and expressed a strong desire for the visit to stick to the safe realms of discussions on bilateral economic cooperation. As a veteran politician who had displayed a consistent and categorical disdain for Tajikistan's Islamic opposition, it is no surprise that Nazarov would hold antiIranian views; and it seems he had not forgotten Iran's support for the opposition during the civil war; remarking to Hoagland that Iran's infrastructure projects in the country were "compensation for the enormous damage" it had done during Tajikistan's early days of independence-a direct reference to Iran's previous support of the IRP and other opposition groups during the Tajik Ci[i] Nar period (Hoagland, 2006a).

Unfortunately for Nazarov his worst fears became a reality. Coinciding with Ahmadinejad's visit to Tajikistan was the Israeli decision to launch a military offensive into Lebanon, ostensibly to attack Hezbollah militants, a group that Iran had provided significant financial and military support for. Ahmadinejad effectively drew Rahmon into this dispute by using his meeting with the Tajik president as a platform to criticize Israel, and to pressure Rahmon into signing a joint declaration condemning Israel's use of force against Lebanon. In unfamiliar territory, Rahmon stressed that Tajiks as part of the "larger community of Muslims of the world" were of the opinion that the Israeli-Hezbollah dispute had to be solved through a "political route" and that Lebanon's territorial integrity and independence had to be respected 
("Iranian President in Tajik Capital," 2006). Even Foreign Minister Nazarov for good measure conducted a volte-face from his earlier private comments to U.S. Ambassador Hoagland, urging the Israelis to put an end to what he called a "real war that has already killed more than 400 peaceful Lebanese residents" ("Iran: Middle East Overshadows," 2006).

The unexpected and uncharacteristic Tajik political commentary on Middle Eastern affairs overshadowed what was meant to be a rather low key bilateral set of discussions surr (Ding agreements in the areas of law and order, tourism, free economic, urrd trade zones, and preferential tariff deals ("Iran: Middle East Overshadows," 2006). Instead, Tajikistan found itself at the center of an international issue that was of little concern to its national interests. However, economic imperatives outweighed the risks $@$ ienating Iran and its new president on his first state visit to the country. Rahmon and Nazarov's hope that bilateral talks would stick firmly to discussions on cultural, commercial, and assistance matters quickly fell by the wayside; and matters only got worse on the second day of Ahmadinejad's visit where he was slated to meet Afghan President Karzai and Rahmon in trilateral discussions (Hoagland, 2006b).

The first trilateral meeting between post-Taliban Afghanistan, Tajikistan, and Iran had been anxiously awaited. Karzai had originally arranged to ${ }^{t}$ Rahmon and Ahmadinejad in Tehran in January of 2006 but rr "consultation" with the United States withdrew due to "domestic issues"-a not so subtle indication that he was pressured by U.S. officials not to attend the meeting (Hoagland, 2006b). Nonetheless, Karzai only played a very low key role during the meeting and his arrival late in the afternoon at Dushanbe from Kabul led to only a short overlap with Ahmadinejad's time in Tajikistan's capital (Joharifard, 2008, p. 74). Despite the international press breathlessly reporting what seemed like an intensification of political relations between these three so-called "Persian states," very little of substance came out of the meeting: the three leaders signing a number of memoranda of understanding in the realms of economic cooperation and also in combatting drug trafficking and political terrorism (Golovina, 2006). Furthermore, Ahmadinejad advocated a range of different cultural projects, which would "reconnect" the three states' peoples.

At the close of the meeting, Ahmadinejad declared simplistically and somewhat falsely, given the ethnic, religious, and linguistic demographics of all three states, that they were "united by a common language, culture, and religion. It's impossible to divide us by borders or talk about our differences... There are a number of global threats that unite us. Security in Tajikistan and Afghanistan increases Iran's security" (Golovina, 2006). In reality however, Afghanistan's strong links and reliance upon the United States to promote its security, as well as Tajikistan's continued relationship with the United States through basing agreements and cooperation, made such a statement awkward for both the leaders of Afghanistan and Tajikistan. However, it would be the discursive salvo Ahmadinejad would launch against the United States during this press conference that would send Tajik officials into a state of further discomfort and annoyance. 
Addressing a large assembly of journalists to announce the agreements that the three leaders had signed, Ahmadinejad waited for both Karzai and Rahmon to exit the press conference before launching into a tirade against the United States, declaring that now he could finally "tell you what I really think," claiming that the United States had "spread slander" against Iran to "conceal its own shortcomings." According to American diplomatic cables, Nazarov had stressed to Hoagland that he had asked Ahmadinejad not to use the meeting as a platform to criticize the United States; however, he could not guarantee that Ahmadinejad would not respond to the "provocations" of the assembled journalists. In later discussions with American diplomats, Nazarov seemed genuinely shocked that Ahmadinejad had used this visit to Tajikistan to express such grievances (Hoagland, 2006b).

The visit by Ahmadinejad to Dushanbe and the subsequent controversy he stirred was a microcosm of Iran's relations with Tajikistan throughout his presidency. Every trip by Ahmadinejad to Tajikistan, and Rahmon to Iran revolved around the signing of numerous memoranda of understanding, promises of large-scale economic investment, and the emphasis upon the apparent political and cultural closeness of the two states. Unfortunately, as can be seen in the above visit by Ahmadinejad to Tajikistan, a number of issues plagued interstate relations between Iran and Tajikistan and would continue to do so for a number of years to come.

\section{Iranian-Tajik Economic Relations}

Nowhere was the disjuncture between rhetoric and the reality of Iran's relations with Tajikistan clearer than in the realm of economic policy and engagement. The Anzob tunnel continued to be a festering wound of exposed rebar and jagged surfaces, which seriously harmed political goodwill toward Iran. This was apparent when in 2013, seven years after project was opened to great fanfare by Ahmadinejad, Tajik Transport Minister Nizom Hakimov declared that he preferred that Iran did not complete the project and that "We wanted to involve Chinese experts to finish the construction of the tunnel; however, some political considerations did not allow us to do so...I would like to choose a Chinese company, as it is very difficult to work with Iranian companies. They say one thing but act very differently" ("Iranian Company to Complete Tunnel," 2013). Hakimov's statement was a damning indictment of Iran's actions in relation to Anzob, ${ }^{15}$ however, there were also a litany of other Iranian projects and proposals which were also held hostage to mismanagement, political manipulation, corruption, underfunding, and the impact of international sanctions that stifled Iran's capabilities to deliver on its economic promises. ${ }^{16}$

The issues surrounding Iranian economic engagement with Tajikistan were evident in the case of its largest Tajik investment, the Sangtuda 2 hydroelectric plant. Sangtuda 2 was viewed by Iranian officials as a showcase of Iranian engineering mastery as well as evidence of Iran's predominant economic role in Tajikistan. ${ }^{17}$ The Tajiks hoped that Sangtuda 2 would be only the first of many Iranian projects which could fulfill the country's hydroelectric ambitions and provide the country with much needed economic independence by 
lowering its reliance upon neighboring, energy-rich U20istan. Very quickly, however, Sangtuda 2 ran years behind schedule and created significant difficulties in Iran-Tajik relations. Initially it was hoped that the project would be finished before Khatami left office in $2005,{ }^{18}$ however, construction did not even begin until 2008, with the contract only awarded to Iranian state-owned company Farab in 2007 (Daly, 2007). Although the main factor behind this delay was the need to secure funds and navigate through Iran's and Tajikistan's byzantine and inefficient bureaucracies, later delays came with the inability to ship construction materials from Iran to Tajikistan via Uzbekistan, a state that had consistently displayed hostility toward both Tajikistan and Iran throughout the post-Soviet period. ${ }^{19}$

With these delays in construction came increased tension between Iranian and Tajik elites as well as continued questions as to the ability of povertystricken Tajikistan to pay back the debts it owed to Iran for the building of the dam. ${ }^{20}$ This tension burst out into the open following the opening of Sangtuda 2 in September 2011. Although Ahmadinejad and Rahmon inaugurated the project to much fanfare, it was not fully completed, with only one of the plant's two $110 \mathrm{MW}$ turbines operating. After further delays which have never been fully explained, Iran planned to finally open the second turbine of Sangtuda 2 in February 2013. However, after Barqi Tojik-Tajikistan's national energy provider-was unable to pay for the supply of electricity being produced from the hydroelectric station and pay arrears amounting to USD 12 million to the Iranian operators, leading to Ahmadinejad postponing his visit (Trilling, 2014). In lieu of this payment Iran took the drastic step of shutting down the station in winter 2013, which only exacerbated Tajikistan's energy crisis (Ergasheva, 2014). Despite earlier claims by Rahmon that Sangtuda 2 was an "outstanding example of cooperation between Tajikistan and Iran," and was evidence of the "rapid development and good future of constructive cooperation between our countries" ("Tajik Leader Praises Cooperation," 2011). The facts on the ground told a different story. Sangtuda 2 remained an economic and political debacle both for the Tajiks who had expected the project to begin fully operating over a half a decade earlier, and to the Iranian government and its state run companies who had lost a significant amount of money on building and operating the project.

Despite the issues that surrounded Sangtuda 2, Iran continued to publicly express a strong willingness to invest in other large-scale hydroelectric projects in Tajikistan. For instance, Iranian Ambassador to Tajikistan Ali Ashgar Sherdoust proclaimed to local media that Iran would be "involved in the construction of the Roghun hydroelectric power station, both at the governmental level and through the private sector" ("Tajikistan: Iran to the Rescue," 2009). The ability for Iran to undertake such a large project, which was slated to cost between USD 2 and 6 billion was fanciful at best and it is highly likely that Sherdoust was engaging in nothing more than a game of political oneupmanship after Russia had backflipped on earlier commitments to fund Roghun's construction (Kucera, 2013b). Only adding to the Iran's publicly professed economic commitments was the Iranian construction company Farab's declaration that following the construction of Sangtuda 2 it would begin construction on the Ayni hydroelectric project. $^{21}$ 
At the time of writing however, Farab, a company with strong links to the Islamic Revolutionary Guard Corp (IRGC) has done very little to fulfill its previously made commitments. ${ }^{22}$ In the wake of the Global Financial Crisis (GFC), and the widening of sanctions ${ }^{23}$ upon Iranian companies linked with the IRGC, it became extremely difficult and far-fetched to say the least for such Iranian companies to invest in Tajikistan. ${ }^{24}$ The impact of these sanctions can be seen in the fact that in 2012, Iran's state investments in Tajikistan had dropped to USD 26 million making it the fifth biggest state investor in the country from a peak when Iran was Tajikistan's leading state investor in 2010 with investment figures amounting to USD 65.2 million. ${ }^{25}$ Furthermore, Tajikistan's at times shady dealings with Iranian businessmen and companies that acted as fronts for IRGC business interests had provided the Tajik government with unwanted international attention, and led to serious misgivings within the Barack Obama administration toward Tajikistan's unregulated financial sector, which had provided a foothold for Iran to avoid sanctions. ${ }^{26}$

The questioning of Iran's economic promises and the Tajiks' unhappiness toward the standard of Iranian investments was a consistent theme that was raised by Tajik elites in private discussions with the author. Iran's empty promises in the construction of a number of large-scale projects, as well as the inability to complete smaller projects such as a three tower residential and commercial complex ${ }^{27}$ that now sits as a wasted concrete shell in Dushanbe's urban heart, was the subject of much anger among Tajikistan's intelligentsia, and denial and embarrassment among Iranian experts interviewed. ${ }^{28}$ Furthermore, despite Iranian and Tajik leaders alike publicly lauding the level of economic interaction and trade between the two states, which had increased from a bilateral level of USD 134.6 million in 2006 to USD 220 million in $2011^{29}$; Iran outside of its large state-driven investments was only a minor player in Tajikistan's broader economy. Privately run Iranian companies for instance, only invested USD 1 million into Tajikistan's economy in 2009, a figure that paled in comparison to Iran's Kazakhstani, Chinese, and Russian business rivals. ${ }^{30}$

Among the failures, there were success stories. For instance, according official Tajik statistics there were a total of 52 Tajik-Iranian joint ventures operating in the country in 2009, and 20 Iranian companies operating in a number of areas such as livestock, poultry production, and detergent making. ${ }^{31}$ The most successful of these ventures included large poultry farms operating in the Sughd and Khatlon provinces, and a tractor manufacturing plant and vegetable oil factory in Dushanbe. Although not of the grand-scale hoped for or claimed by Iran's president, it appeared that if Iranian policy planners had accepted their limited capabilities and stuck to much more realistic economic goals in Tajikistan, Iran could have achieved much more success and been the recipient of substantial political goodwill.

\section{Iranian-Tajik Cultural Engagement}

Apart from Ahmadinejad's strong push to improve Iran's economic position in Tajikistan was his focus on cultural diplomacy. Ahmadinejad often claimed that Iran and Tajikistan were like "one spirit in two bodies" and that 
the two states' "single history, culture, tradition and religion" had made them inseparable (Kroth, 2012). Such rhetoric flew in the face of the widely held view within the international community that Ahmadinejad was nothing more than an Islamist hardliner or revolutionary fanatic, and exposed Iran's pragmatic use of its national culture and history for political and strategic purposes. ${ }^{32}$ Ahmadinejad sought to use Iran's history and civilization as a means to bridge political divides and to emphasize commonality with his Tajik counterparts and as a means to avoid wider regional isolation in the face of international pressures. Although warmly embraced by Tajikistan's intelligentsia, and viewed favorably by Tajikistan's government who had consistently sought to keep Iran's ideology and Islamic proclivities at armslength, Ahmadinejad's cultural diplomacy efforts were not free from the controversies and issues that dogged Iran's wider foreign policy agendas; and unfortunately for Ahmadinejad his endeavors were often stymied by mismanagement, over-exuberance, and lingering suspicions relating to Iran's "real" intentions.

During Ahmadinejad's presidency, he firmly supported the extension and promotion of Iranian arts and cultural festivals, and programs which sought to bolster Persian language and literature in the country, many of which had begun during the time of his predecessor Khatami. He oversaw the sponsoring of Tajik intellectuals to travel to Iran, and provided stipends and funds for the publication of their works into both the Persian and Cyrillic alphabets (Malekian, 2012, pp. 97-98). The Ahmadinejad administration also oversaw the establishment of 17 cultural centers throughout Tajikistan where Tajik students learned how to read and write in Persian, study the Koran, and also had access to Iranian films, magazines, books, and other materials (Sanaei, 2011, pp. 270271; Sodiqov, 2011b). ${ }^{33}$

These programs were a continuation of policies and actions that had long predated Ahmadinejad's presidency and while continuing to support these activities, Ahmadinejad and his administration also sought to institute much grander plans, which would use Iranian culture and national history as a key diplomatic tool to build and improve Iran's political influence in Tajikistan and the wider region. For instance, Nowruz-an ancient Zoroastrian festival celebrating the beginning of the vernal equinox, which had been banned for much of the Soviet period in the Central Asian and Caucasus regionsbecame a cornerstone of Ahmadinejad's cultural diplomacy efforts (Marat, 2007; Sanaei, 2011, p. 262). Although all of the Central Asian republics had openly celebrated Nowruz since the fall of the Soviet Union, Ahmadinejad's administration encouraged state leaders within the so-called "Iranian plateau" such as Tajikistan, Afghanistan, Iraq, Kurdistan, Azerbaijan, and the other Central Asian Turkic republics to use the occasion as a means to increase political dialogue (Mirsanjari, 2010). The "International Nowruz Festival" which brought these states together was first held in Tehran in 2010 and 2011, and held in the following years in Tajikistan, Turkmenistan, and Afghanistan. The International Nowruz Festival became an institution for the region's leaders and was used as a means to strengthen regional stability, and promote "brotherhood." According to a number of Iranian political experts this initiative was one of Ahmadinejad's key regional foreign policy 
achievements and served a dual purpose in not only promoting regional friendship and cultural commonality but also allowed Iran another much needed international platform to highlight its political grievances and fulfill its ambition to be seen as a regional leader (Dareini, 2010).

Another prominent initiative within the Ahmadinejad administration's cultural diplomatic efforts was the establishment of the Persian Speaking Association between Iran, Tajikistan, and Afghanistan. ${ }^{34}$ This association stemmed from the first trilateral meeting that took place between Rahmon, Karzai and Ahmadinejad in January 2006 and sought to promote political and cultural commonality between the three states as well as to discuss measures to address the geographical, economic, and political isolation all three continued to suffer. This somewhat informal association between the three states was often breathlessly referred to as an "alliance" and a "union" among regional observers, and without doubt Ahmadinejad was confident that building upon perceived notions of cultural commonality this association could eventually catapult itself into the realm of a political and strategic alliance (Medrea, 2008). Ahmadinejad's enthusiasm for expanding political relations through the Persian Speaking Association was shared, rhetorically at least, by Rahmon who hoped this initiative could balance the influence and pressure of Uzbekistan, and provide Tajikistan with its own regional grouping to rival the Turkish-Speaking Association made up of Kazakhstan, Uzbekistan and the Kyrgyz Republic (Mahmoudi, 2009). However, Afghan President Karzai did not share his two counterparts interest in developing closer political links and displayed only very limited interest for what became one of Ahmadinejad's pet projects. Karzai was well aware that the extension of the association beyond informal cultural links to a political or strategic alliance would be unacceptable to his American backers who continued to bankroll his government and acted as a domestic security guarantor within his country (Joharifard, 2008, pp. 77-78). Furthermore, Afghanistan as a multilingual and ethnic state, where $35 \%$ of the population spoke Pashto made such a project highly problematic. Apart from these obstacles the Persian Speaking Association rarely instigated any policies of real substance and often descended into nothing more than a talk-fest of over the top rhetoric and commitments to cooperation, which sounded good on paper and at news conferences but often failed in practice.

A prominent example of the association's failure to instigate even the most modest of agendas was the attempt to establish a joint television station, which would air shared content and promote the three states' so-called "shared Persian culture." Regrettably, this initiative became yet another symbol of Iranian missteps in Tajikistan and the broader region. At the first trilateral meeting between the three leaders in July 2006, Ahmadinejad had first advocated this project ${ }^{35}$; but it was not until July 2008 that a working group of Iranian, Afghan, and Tajik ministers inked an agreement on the establishment of the joint television station, which would be headquartered in Dushanbe and televise programs and news from all the three states and begin operating in the "very near future" ("Iran, Tajikistan, Afghanistan," 2008; Najibullah, 2008). By 2010, the joint television station was still not in operation, although it was claimed by Tajik Culture Minister Mirzoshohrukh Asrori that the station would begin airing during the annual Nowruz 
celebrations in March 2010 ("Persian-Language TV Station," 2010). When interviewed by international news media outlets, Iran's Ambassador to Tajikistan, Sherdoust, claimed that the delays in the project had come about due to "reservations" held by Afghan authorities toward the television channel and that the issues would be "resolved soon." Despite the claims by these two political figures, the television station did not begin operations in March 2010, nor were the "issues" surrounding the project ever resolved.

Speaking two years later, Sherdoust said that the Tajik authorities now had the television equipment and if they would allow it to be installed the channel could start operating. Unfortunately, the Tajik authorities did not allow the equipment to be installed, and by 2012 were demanding that the Iranian Embassy pay customs duties totaling USD 400,000 for the importation of the equipment which had cost Iranian authorities over USD 2.5 million to purchase in the first place ("Tajik Customs Agents Hold Iranian Gear," 2012). Tajik customs officials claimed that the duties would be waived if the equipment was to be used strictly by the embassy; if not, however, the duties would indeed have to be paid. At the time of writing the television equipment remains in a Tajik customs' warehouse and eight years since the initial proposal there remains no joint Iranian, Afghan, and Tajik television channel to speak of. While publicly the reasons for this delay have been put down to miscommunication, technical difficulties, Afghan disinterest, and other seemingly "minor issues," the real reason came down to the fundamental differences that existed between Iran and Tajikistan's societies and forms of government. ${ }^{36}$ Tajikistan's staunchly secular government, despite the public professions to the contrary, neither had the time, nor the inclination to support the programming of Iranian television content, particularly content that was religious in nature (Marat, 2007). This is confirmed by a Tajik expert who noted that:

The common TV channel for Iran, Afghanistan and Tajikistan - this so called Persian, Farsi speaking channel has failed mostly because of the Tajik position....Afghanistan also hampered the project for their own reasons. But the major obstacle was the position of the Tajik government. (Tajik International Relations Scholar, 2013)

This view was supported in an interview with a former State Advisor to the Tajik President who said he was made aware by Tajik government colleagues almost immediately after the signing of the television agreement with the Iranian government that the project "was impossible" to implement. In particular, Tajik elites were concerned with the appearance of females wearing the hijab on television and the influence of Iranian Islamic mores upon Tajik society: "Iranian TV does not show what Tajik TV shows. A woman with an open face, a working woman, a singing woman, a talking woman...Unless the political issue - that is the [Iranian government's attitude towards society] is not solved, this television station will not be organised" (Fo D P State Advisor to the Tajik President, 2013). When asked publicly about this very issue the chairman of the Tajikistan Committee for Television and Radio Broadcasting, Asadullo Rahmonov declared that if the Iranian government insisted that Tajik female presenters wear the hijab on programs airing on the proposed television network, then "we will insist that Iranian female [presenters] do not wear hijab" ("Iran 
Delaying Tajik-Afghan-Iranian TV," 2011). While Rahmonov claimed that he had made these comments in jest, the reality is that Tajikistan's government continued to have underlying suspicions about Iran's religious ideologies, and the nature of its cultural influence in the country.

These fears were perhaps justified when considering that for nearly every Iranian project that promoted strictly Persian culture and language were others, which were seemingly much more opaque in their intentions and priorities. For example, Radio Tajiki, also known as "The Voice of Khorasan," with its links to the IRGC, promoted Iranian government views on international political issues and described its mission as: "Familiarizing audiences with Islam and the message of the Islamic revolution and the propagation of the pure ideas of the founder of the system of the Islamic Republic of Iran, Imam Khomeini" (Vinson, 2012b). Furthermore, Iranian organizations such as Imam Khomeini Relief Foundation (IKRF) which since independence has been one of the major aid organizations in Tajikistan, expanded their presence during Ahmadinejad's term in office. In 2005, IKRF had supported 26,670 individuals; by 2008-2009 this figure had increased to over 33,643 individuals under IKRF's "protection" (Imam Khomeini Relief Committee, 2 (12009). ${ }^{37}$ As a humanitarian organization much of IKRF's aid came in the form of food, clothing, medical support, education, job creation enterprises, and scholarships, and also dowries for young Tajiks wishing to get married. Although this aid was much needed and provided Tajiks with educational and other opportunities, a number of Tajik elites interviewed, in particular a highly ranked former foreign ministry official, perceived IKRF as a Trojan horse for the spread of "Shi'ite values" in the country (Former Tajik Government Official, 2013).

In addition to this expansion of the presence of IKRF, Iran also increased the availability of stipends and scholarships for Tajik students to study in Iranian universities and madrassas, which caused consternation within the Tajik government and contributed to behind the scenes tension among the elites of both states. Responding to fears that Tajik students were being inculcated with fundamentalist Islamic values, which could destabilize the country, Rahmon ordered almost 1,400 Tajik students studying in madrassas and Islamic universities in neighboring countries to return home. Declaring that if Tajik parents did not recall their children from foreign madrassas and Islamic universities the majority of the students "may turn into extremists and terrorists in five or ten years' time" (Lemon, 2010). Of these 1,400 students, almost 200 were studying in Iran. There was particular suspicion in relation to Tajik students adopting Shi'ism in Iran and attempting to bring these values into the country by organizing study groups and other gatherings. ${ }^{38}$ Thejik government also cracked down upon Iranian educational efforts within the country, ordering a local school run by the Iranian Embassy to expel 90 Tajik students, as well as 150 Afghan students. The official explanation given for the closure was that the school only had accreditation to teach children of local Iranians, Iranian diplomats, and embassy support staff.

Seeking to tiptoe around these issues and not interfere in Tajikistan's domestic politics, Iran's Ambassador to Tajikistan Sherdoust declared in an interview (while also conveniently forgetting his own government's 
interference in its citizen's religious and personal rights) that he felt that "beliefs and religion are personal matters and governments should not obstruct people's beliefs. . Religion is a personal matter; no government can take away my religion. I personally believe that governments should not interfere with it" (Trilling, 2012). In conversations with a current Iranian Ambassador of a neighboring regional country, who has had signifigan professional experience in Tajikistan and the wider region, expressed g concern toward the Tajik government's position in respect to Islam, and while he unequivocally declared that Iran did not interfere in Tajikistan's domestic policies on religion, he felt that the country had made the wrong decision in its crackdown on Islam and in particular toward students wishing to study in Iran. In fact, he felt that by instituting such anti-Islamic agendas, radicalism would only grow in Tajikistan and contribute to future instability (Iranian Ambassador, 2013). Most Iranian scholars interviewed felt that Tajikistan's hostility toward Islam would continue to act as a challenge toward Iran's cultural agendas into the foreseeable future, and that while Iran's money was welcome its influence was not, despite the brotherly public rhetoric to the contrary.

\section{Iranian-Tajik Political and Strategic Engagement}

The Ahmadinejad administration, although couching the motivations for its focus upon Tajikistan in terms of charity, cultural commonality, and concern for its economically poorer Tajik "Persian brothers," was driven firmly by strategic and hard-edged political concerns. However, despite leaders in both states loudly proclaiming that Iranian-Tajik relations constituted a strategic partnership; substantive engagement, and measurable actions to support such discourse was sorely lacking even by the close of Ahmadinejad's second term (“Tajik Leader Upbeat," 2010; “Tajik President Meets," 2008). Iran's ability to carry through on its leader's rhetoric was very difficult in light of its political and economic emaciation following the imposition of economic sanctions and international isolation. However, a much more influential obstacle was Tajikistan's reluctance to go beyond words to deeds, and its continual and shrewd efforts to take advantage of regional political rivalry to exact political and economic benefits from Iran, bringing into question the rhetoric of political and strategic closeness between the two states.

From the outset of his presidency, Ahmadinejad had declared that there would "no limit" to Iran and Tajikistan's relations and that the development, security, independence, and dignity of Tajikistan was Iran's top priority ("Ahmadinejad Sees No Limit," 2006). Ahmadinejad not only attempted to promote close political ties with Tajikistan on a trilateral level through the Persian Speaking Association with Afghanistan (the outcomes of which had been quite modest), but also bilaterally encouraging Tajikistan to sign cooperation agreements in the realms of antiterrorism in trafficking, and military assistance. More important was Ahmadinejad's apparent success in enlisting Rahmon and his Tajik colleagues to publicly support Iran's "right" to peaceful nuclear energy. Rahmon insisted on a number of occasions that it was perfectly legitimate for Iran to pursue a nuclear energy program, and asserted that a diplomatic solution needed to be found in the ongoing crisis between 
Iran and the West ("Tajikistan Backs Iran's," 2010; "Tajikistan Supports Iran's," 2010). ${ }^{39}$ However, behind closed doors Tajikistan's leaders were not as resolute in their support of Iran as they were in public, especially in the audience of Western diplomats.

As already noted, Tajik elites detested the prospect of finding themselves ensnared in Iran's political and diplomatic problems and consistently sought to avoid being drawn into international controversy. Nonetheless, as the nuclear dispute heated up, they would increasingly find themselves involved in an international feud they wanted very little part of. By soliciting Iranian economic investment, Tajikistan was expected, if not compelled by Tehran, to support its nuclear program, while at the same time cajoled and often bullied by officials in Washington to "do more" to convince Iran to come to the negotiating table and to cool political and economic ties with the Islamic Republic (Hoagland, 2006d). In conversations with American diplomats, Tajik elites displayed incredulity toward Iran's "reckless" stance on the nuclear dossier and declared that they were against the prospect of Iran gaining nuclear weapons; however, they were adamant that they would not confront Iran on this issue because they needed Tehran's financial and political support (Hoagland, 2006e). ${ }^{40}$ If the United States would have been willing to fill the economic gap provided by Iranian investment, Tajikistan's public stance on the Iranian nuclear issue arguably may have been very different.

Tajikistan's somewhat contradictory and fickle behavior toward Iran was also evident in other contexts such as in its tense relationship with neighboring Uzbekistan and its at times complicated ties with major patron, Russia. Dushanbe and Moscow had rarely seen eye-to-eye with Uzbekistan, who had since 2001, become a darling in the eyes of the West due to its prominent role in the so-called "war on terror." In 2005 however, Uzbekistan's dalliance with the West, in particular the United States, came to an abrupt end following the "Andijan massacre," which saw the Uzbek government allegedly kill hundreds of people who had protested the imprisonment of 23 men who had been accused of Islamic extremism. The U.S. criticism of Uzbekistan's handling of this incident and of its abysmal human rights record led to Uzbekistan unceremoniously kicking out American military forces based in the country.

Sensing its growing regional and international isolation, the Karimov regime quickly sought out new allies, and in an about face attempted to realign itself with Russia. These Uzbek actions were unsurprisingly welcomed in Moscow, where Russian elites were happy to again bring Uzbekistan within their political orbit, following the consistent setbacks Russia had faced in Central Asia following the U.S.-led invasion of Afghanistan. However, the potential warming of ties between Tajikistan's major foe and its traditional security guarantor created shockwaves in Dushanbe where there was a fear that Moscow was turning its back on Tajikistan in favor of Uzbekistan. ${ }^{41}$

Such fears were placed into sharp relief following Uzbek President Karimov's highly touted visit to Moscow at the end of 2007, in the midst of massive energy shortages and a food crisis caused partly by unilateral Uzbek blockades of Tajikistan's borders and energy grid. Following Karimov's visit to Moscow, Rahmon also sought out new partners, and in a surprise move 
went to Tehran where he solicited Iranian political and economic support for his country. This visit was portrayed as a major development by the Tajik media, who lauded Iran's contributions to alleviating Tajikistan's energy and food shortages (US Embassy, 2008). Abdulloh Rahnamo of Tajikistan's Strategic Research Center noted that Russia had historically been Tajikistan's "best partner" but its changing position in regard to Uzbekistan had left the country in a "hard situation," meaning that Tajikistan's government desperately required new international partners, and was much more amenable to pursuing relations with Iran in this context (US Embassy, 2008).

Adding impetus for Tajikistan to continue pursuing strong ties with Iran was the Russian company Rosul's decision to cancel its investment in the Roghun hydroelectric project in 2008. Roghun had been intensely opposed by Uzbekistan, who feared that the size and scale of the project, which would have been one of the largest hydroelectric dams in the world, could threaten downstream water flows into the country and ruin its most important industry, cotton farming. Tajik experts viewed the decision by Rosul to cancel the contract as only a further symbol of Russia's "siding with" Uzbekistan in its long running feud with Tashkent over water and energy supplies (Nourzhanov, 2012, p. 371). This decision by Moscow only accentuated the apparent rift between Tajikistan and Russia, leading Rahmon to cancel a meeting with Russian President Dmitry Medvedev in early 2009, while inviting Iranian trade and defense ministers to Dushanbe in a not so subtle nod toward Tehran at Moscow's expense (Najibullah, 2009).

Tajikistan's courting of Iran to balance the threat of Uzbekistan and to perhaps step into the breach left by Moscow's warming relations with Tashkent was duly accepted by Iran. Whereas former Iranian presidents Khatami and Rafsanjani had largely attempted to take a neutral stance in the plethora of Central Asian political squabbles and not involve Iran in the seemingly never ending disputes between Tajikistan and Uzbekistan, Ahmadinejad and his colleagues showed no such restraint. Ahmadinejad strongly supported the construction of the Roghun and Ayni hydroelectric power projects, which had been aggressively opposed by Tashkent, and also was a strong critic of Uzbekistan's blockade of Tajikistan. Ir n strong support of Tajikistan was evident in the comments made by Ahmadinejad's close ally, former First Vice President, and Presidential Chief of Staff Esfandiar Rahim Mashaei in response to Uzbekistan's blockade of rail freight into the country, and its opposition to hydroelectric projects. Mashaei disagreed strongly th Uzbekistan's stance on Tajikistan and stated that Tashkent could notrew its relations with Iran separately from those with Tajikistan. Furthermore, he declared that "the government of Iran stands by the state and nation of Tajikistan. We regard this as a strategic policy and will not desist from it. It is our policy to expand our cooperation with Tajikistan in a strategic manner" (Nourzhanov, 2012, p. 372). The local media in Tajikistan breathlessly reported the words of Mashaei and claimed that Karimov had finally "been defeated," but Uzbekistan continued its blockade, thus ignoring what ended up being nothing more than empty Iranian rhetoric (Nourzhanov, 2012, p. 372). 
As tensions between Tashkent and Dushanbe continued into 2011, Tajik Defense Minister, Sherali Khairulloyev shocked many when he declared during a visit by Ahmadinejad that:

Today, if necessary, the Islamic Republic of Iran's Armed Forces can reach Tajikistan in two hours...We support each other under any conditions and both friends and foes consider us as two friendly and brotherly countries. (Kucera, 2011)

According to a number of Tajik experts, this statement by Khairulloyev was not only pointed toward Uzbekistan, but also Russia which was in the process of negotiating a new military basing agreement with the Tajik government. In comments made to Eurasianet, Arkady Dubnov-a journalist and Central Asian expert-opined that "Rahmon's dalliance with Iran is aimed at Russia; telling Moscow that it has other friends who could protect it, too" (Kucera, 2011). However, Iran's inability to pursue a substantive strategic partnership with Tajikistan was made clear only a couple of days later, when a small contingent of Iranian soldiers was invited to attend Tajikistan's Independence Day parade. As the troops embarked upon their journey from Iran, their flight was blocked from entering Turkmen and Uzbek airspace. The Iranians were forced to reroute "ironically through Afghanistan, whose airspace is controlled by NATO and the United States" (Y
2011).

Despite the Tajik government's embrace of Iran, elites in Dushanbe knew that without Moscow's military and political support the country would be placed at the mercy of a much stronger Uzbekistan and would also leave it much more open to instability emanating from its southern Afghan border. Despite what was a bumpy patch in relations with Russia, Moscow's integral role in Tajikistan was confirmed in October 2013, when the Tajik parliament ratified a deal extending Russia's military presence in the country for another three decades. While numerous defense pacts and cooperation agreements were signed throughout Ahmadinejad's presidency, Tajikistan showed very little interest in building substantive cooperation with Iran in this field. This was aptly pointed out in an interview between the author and an Iranian Central Asian Foreign Policy Expert (2013) who declared that:

\begin{abstract}
We sign many agreements with Tajikistan, but I would not call Iran's relationship with Tajikistan as strategic. The Tajik government has not and never will allow Iran to establish military bases there, they have never sent their military officers here to Iran for training, and we never have joint military manoeuvres...it is very difficult to say that Iran and Tajikistan have a strategic relationship.
\end{abstract}

By the close of Ahmadinejad's presidency in 2013, Iran remained a very minor player in Tajik strategic affairs despite the public rhetoric to the contrary. Iran as a "strategic partner" to Tajikistan was much more a myth than a reality. Instead, Tajikistan often used Iran in a manipulative fashion to improve its strategic value and ward off regional threats, particularly in the context of its relationship with Uzbekistan. In the Machiavellian world of international politics Tajikistan, a small and insecure state, 
understandably put its own strategic and political self-interests above all else, and it seems unlikely that the country ever seriously pursued a strong strategic relationship with an Iran that was increasingly under siege and isolated.

\section{Conclusion}

Although Ahmadinejad and his administration placed a significant emphasis upon building multifaceted cultural, economic, and political relations with Tajikistan, Iran was largely unable to fulfill its agendas. The impact of sanctions, international isolation, and regional rivalry often left Iranian-Tajik relations at the mercy of factors far beyond either state's control. It is also apparent that despite the friendly rhetoric exhibited by elites in both states, tension and suspicion often lay just below the surface of the bilateral relationship. Tajikistan's elites while publicly stating their willingness to engage substantively with Iran in all facets, were in practice less sanguine at the prospects of deep ties. Iran was often viewed with caution among some segments of Tajikistan's political elite, especially those who held strong secular biases. Iran did its best to overcome these suspicions by focusing heavily upon the cultural bonds that were believed to exist between the two states and did make some strong inroads in creating goodwill among Tajikistan's public. Nonetheless some of Iran's more religiously ambiguous cultural programs and initiatives did little to prevent suspicions that Iran held an Islamist agenda in Tajikistan.

While Iran may not ever overcome the Tajik government's fears toward its Islamic nature and political heritage, this factor played very little role in contributing to the underlying issues that have plagued its relations with Tajikistan in recent years. Rather, the main factor that limited Iran's interactions with Dushanbe was the consistent mismanagement of this interstate relationship by Iranian political elites. Iran throughout Ahmadinejad's presidency promised a lot but at times gave very little. Many of Iran's economic projects suffered from funding issues, or technical shortcomings, which were ignored for the sake of an often misguided desire to display that Iran was somehow Tajikistan's "foremost international partner." Compounding this theme of mismanagement was the fact that on almost every visit to Tajikistan by Ahmadinejad and his cadres, a new political and economic commitment was made or an agreement signed that Iran had little intention or ability to fulfill. These actions spoiled Iran's reputation among Tajikistan's political elite, many of whom would often question both in public and in private, Iran's reliability as an economic and political partner.

Unfortunately for Iran, the great hopes of a deep, multifaceted IranianTajik relationship have yet to come to pass. Although Iran and Tajikistan share many common bonds, which will ensure relations into the future, Iran has not done enough to use its cultural, political, and economic assets to best effect in Tajikistan. Despite claims to the contrary, Iran remains a secondary player in Tajikistan and does not wield the influence so often portrayed both within Iran and the wider international community. Instead, Iran's relations with Tajikistan, particularly during the period of Ahmadinejad's presidency is a prominent, yet understudied example of Iranian foreign policy 


\title{
dysfunction, and its underperformance in a context and country where it should be playing a much more substantial role.
}

\begin{abstract}
Notes
${ }^{1}$ Ahmadinejad held six visits to Tajikistan during his eight year presidency.

${ }^{2}$ For discussion of the differing ideologies and interests of the opposition parties, see Khudonazar (1995), Mullojonov (2001), and Nourzhanov and Bleuer (2013).

${ }^{3}$ For a full analysis of the IRP's ideological influences and its links with Iran, see Nourzhanov and Bleuer (2013, pp. 231-275).

${ }^{4}$ In the bluntest of terms, a former Iranian statesman with significant firsthand diplomatic experience in Tajikistan and Central Asia summed up the Tajik Civil War to the author as follows, "That war in Tajikistan was a village conflict! It had nothing to do with Islam!" The official went on to declare that although there were "of course Muslim forces present in the conflict," overall the Tajik Civil War had nothing to do with Islam, or much more broadly a "Communism versus Islam dynamic" (Former Iranian Ambassador, 2013).

${ }^{5}$ Only three weeks after the death of Ayatollah Khomeini in 1989, Iran's Speaker of Parliament and future President, Ali Akbar Hashemi Rafsanjani made a historic visit to Moscow, signing a number of trade, economic, and military technical assistance contracts worth almost USD 6 billion.

${ }^{6}$ For example see Keyhan's stinging commentary which declared that the Iranian government's "wariness" to describe the war in Tajikistan as an "Islamic" conflict alongside the Iranian foreign ministry's unwillingness to take an "appropriate position that befits Iran's position as Islam's leader" was a miscalculation that would hurt Iran's reputation in the wider Islamic world ("International Silence' on Tajikistan Assailed," 1992).

${ }^{7}$ For instance, in 1996, President Rahmon accused Iran of being a training ground for "terroristic activities." See “Iran Denies Involvement," (1996).

${ }^{8}$ The Tajik government had shelved earlier initiatives to instigate language reforms, and continued to teach in the Cyrillic alphabet. Apart from an Iranian cultural center in Dushanbe, there were very few opportunities for Tajiks to learn the Arabic alphabet. Debt issues and other problems often saw the cancellation of flight routes between the two states. For example, see "Tajik Airline Resumes Weekly Flights" (1998).

9Dialogue of Civilizations was Khatami's direct response to the so-called "Clash of Civilizations" thesis that had been popularized in the work of Samuel P. Huntington. According to Huntington, the fault lines of future conflict would be based on civilizational and cultural differences rather than ideological ones. See Huntington (1993, pp. 22-49). Khatami asserted that diversity and plurality among civilizations was a matter that could be overcome through dialogue and cooperation among scholars, thinkers, and politicians of the international community. With this idea, Khatami sought to replace the centrality of conflict in Iran's foreign policy discourse to one of cooperation. For further discussion, see Hunter (2010, p. 77), Hussain (2002, pp. 73-85), Pahlavi and Hojati (2010, p. 221), and Sariolghalem (2000, pp. 1-38).

${ }^{10}$ For example, Russia reinforced its presence in Tajikistan in 2004, with the 201st Motorized Infantry Division establishing a permanent base in the country. Additionally, in early 2004, Rahmon granted Moscow military basing rights in Tajikistan "on a free of charge and open-ended basis" (see Berman, 2004, p. 65).

${ }^{11}$ For an excellent and thorough analysis of the impact of Uzbek blockades and the geographical difficulties faced by the Tajik economy, see Umarov (2007, pp. 107-140).

${ }^{12}$ In early 2003 for instance, Iran pledged USD 500 million to Afghan reconstruction efforts (Dobbins, 2010, p. 204)

${ }^{13}$ Ahmadinejad consistently proposed a "new world order" of multiple centers of power, which could confront the "global arrogance" of the United States. Key to this "new world order" would be the establishment of a strategic partnership between Iran and states such as China, Russia, and India (see Kucera, 2013a; Hunter, 2010, p. 14; Vakil, 2006, pp. 51-65).

${ }^{14}$ The author experienced traveling through the Anzob tunnel first hand in June 2013. For an indepth description of its poor construction, see Trilling (2007).

${ }^{15}$ Iranian company Sobir had promised to provide USD 6 million to rectify the problems with Anzob, but nothing had been done. According to the Iranian government, Anzob's problems and the delays in fixing them did not stem from Iran but were in fact due to power outages, cement shortages, and heavy taxation imposed by the tax office in Tajikistan. See "Bahr Mabradar-ye az Faz 2" (2013).

${ }^{16}$ Iranian proposed projects were often so large in scale and ambitious that many experts interviewed by the author questioned the ability of the Iranian government to carry out the construction of such projects. Commenting on this issue, Sodiqov in a scathing article outlined a number of these projects which remained unimplemented. The most notable of these projects were an "Industrial City" and a USD 500 million cement factory in Khatlon, however, smaller projects such as health clinics, a tourism college, and a university also seemed to remain in perpetual limbo. See Sodiqov (2012).
\end{abstract}




\begin{abstract}
${ }^{17}$ No discussion with any Iranian expert or political elite could take place without mention of Sangtuda 2 and its importance to Tajikistan.

${ }^{18}$ Talbak Nazarov in conversation with the U.S. Ambassador to Tajikistan Richard Hoagland declared that he had hoped that Sangtuda 2 would be finished before Khatami left office. See Hoagland (2006a).

${ }^{19}$ Uzbek authorities had instituted a rail blockade upon Tajikistan in 2010 in an attempt to stop the dam's construction due to fears it would stem the flow of water to Uzbekistan's large cotton growing sector. Although Iran threatened Uzbekistan with its own blockade on Uzbek rail cars entering Iran, Uzbekistan only lifted the blockade for a short period of time. In response, Iran had to take the expensive step of airlifting the plant's transformers and turbines and other construction equipment totalling over 75 tons from Iran to Tajikistan, which further delayed the project, and highlighted Iran's powerlessness in exerting pressure on Uzbekistan.
\end{abstract}

${ }^{20}$ Under the initial agreement with Tajikistan, Iran had pledged to contribute USD 180 million toward the USD 220 million project. To cover the costs in construction, Iran had intended to own and operate the plant over 12 and a half years. However, with construction delays and cost over runs serious tension between Iranian and Tajik officials ensued and it was unclear if, when, and how this money would be paid back to Iran. By September 2011, it was estimated that the total cost of the project had blown out by a further USD 36 million. See "Ahmadinejad Says Iran" (2011) and Vinson (2012a).

${ }^{21} \mathrm{Ahmadinejad}$ was a staunch advocate of the $130 \mathrm{MW}$ Ayni hydroelectric station, so much so, that on almost every visit to Tajikistan between 2010 and 2013 he would either sign another commitment to its construction or announce that Iran would start construction soon; much to the bemusement of Tajik experts interviewed by the author. For further information, see "Ahmadinezhad Says" (2011) and "Iran, Tajikistan Ink Agreement" (2011).

${ }^{22}$ As of July 31, 2014, the Farab website states that Ayni is still in the "under study" stage. See Farab Energy and Water Projects (2014).

${ }^{23}$ According to some estimates the GFC led to a $41 \%$ drop in trade between Iran and Tajikistan in 2009. See Farrar-Wellman \& Frasco (2010). Sanctions had a range of differing impacts upon TajikIranian relations. For instance, following the $30 \%$ drop in the value of the Iranian Rial in late 2012, Tajikistan canceled flights to Iran due to the difficulty in converting currency and paying for aviation fuel purchases. See "Tajik Air Cancels Flights" (2012).

${ }^{24}$ For further discussion on IRGC linked companies and Tajikistan, see Vinson (2012a).

${ }^{25}$ See "Iran 5th Biggest Tajik Investor" (2013) and Shodon (2011). Rahmon himself noted that sanctions had prevented Iran's participation in the Tajik economy. See "Tajik president says" (2012).

${ }^{26}$ Babak Zanjani, an Iranian businessmen who had close personal links with Rahmon, was arrested following the election of Hassan Rouhani in 2013. Zanjani has been accused of laundering Iranian oil money into Tajikistan to fund his business operations, which included, but was not limited, to a taxi company, bus service, airline and bank ("Tajikistan: Where Iranian Money," 2013) Aside from these issues with Tajikistan's financial sector, the Obama administration actively sought to discourage Tajikistan's economic links with Iran. For instance, during a press conference in Dushanbe on March 27, 2012, Robert Blake, Assistant Secretary of State for South and Central Asian Affairs called on Tajikistan and the other Central Asian republics to cut their links with Iran. When asked about the question of Iran's participation in regional infrastructure projects, Blake replied: "Let me just say that consistent with America's sanctions on Iran, the United States is encouraging all of the countries of the region to avoid trade and other transactions with the government of Iran in order to pressure Iran to engage with the international community about its concerns about Iran's nuclear program. We believe there are some very good alternatives." See Blake (2013).

${ }^{27}$ This project known as the Burji Sulh was intended to consist of three towers, which would house conference rooms, apartments, restaurants, and conference facilities. See Mannonov (2006).

${ }^{28}$ For instance, when asked about Anzob, Iranians interviewed often claimed that tunnel was completed and was of an excellent standard, and even though these claims were challenged by the author, those interviewed nonetheless stood by their claims.

${ }^{29}$ Accurate trade figures for 2012 and 2013 are unavailable. Furthermore, figures quoted by Iranian and Tajik news agencies are highly exaggerated, and their accuracy should be questioned. However, it was widely reported that trade between the two states had hit USD 250 million in 2012, while the bilateral trade amounted to USD 229 million in the first nine months of the 2013, of which Iran's imports contributed to USD 128 million of this figure. Iran's imports constituted almost $90 \%$ of this trade flow. See Observatory of Economic Complexity (2014) and United Nations Comtrade (2014).

${ }^{30}$ Comments made by Toghaimurod Hamdam, Chief of the Investments and Economic Reforms Department of the Tajik President to the U.S. Embassy staff. See US Embassy (2009).

${ }^{31}$ Information given by Hamdam in US Embassy (2009). Despite numerous claims by Iranian and Tajik officials, Iran's economic footprint in the country was much more modest than advertised. For instance, it is often suggested that there are over 150 Iranian companies operating in the country. For 
example, see "Envoy: Iranian Companies Implementing" (2013), “FM: Iran-Tajikistan Trade” (2013), and "Tajik Parliament Speaker" (2012).

${ }^{32}$ For a full discussion and analysis of Ahmadinejad's use of national identity in shaping Iran's relations with Tajikistan, see Clark (2012).

${ }^{33}$ The author visited an Iranian cultural center situated on Rudaki Avenue in Dushanbe in June 2013. This small facility offers free access to an adjoining library, and provides locals free tuition in Persian language four times a week. According to staff, on a daily basis at least 10 students use the facility.

${ }^{34}$ For an in-depth analysis of the Persian Speaking Association, see Joharifard (2008).

${ }^{35}$ However, the idea of a joint television channel had a long history, with Rafsanjani first floating the idea in 1991. See "Afghan Government" (2010).

${ }^{36}$ Not to mention the differences with Afghanistan which is demographically split among a number of ethnic groups, the most dominant of which are the Pashtuns. Furthermore, Afghanistan's vibrant and comparatively open and well-funded media sector would place such a joint TV channel at a major competitive disadvantage. Many political figures including Sherdoust also claimed it was the Afghan government that had delayed the project. See "Afghan-Iranian-Tajik TV Project" (2011).

${ }^{37}$ Furthermore, according to Vinson the works of a number of prominent Iranian Shi'a clerics are translated into Tajik Cyrillic and promoted by local Tajik thinkers such as Saidyunisi Istaravshani on Tajik websites. Even the former Qazi Qalon of Tajikistan and deputy leader of the IRP, Akbar Turajonzoda who has had historically strong links with the Iranian government has had his religious affiliations questioned. Many local Tajik elites claim Turajonzoda has converted to Shi'ism and is engaging in "dissimulation" as a means to promote Iranian religious and political views.

${ }^{38}$ For an in-depth discussion of madrassas in Iran that are often frequented by Tajik religious students, see Peyrouse \& Ibraimov (2010). Apart from religious students, there were 630 Tajik university students studying a range of different subjects in Iran, and 950 Iranian university students were studying in Tajikistan in 2009. See Hasanova (2009). For suspicions of Shi'a, see "Tajikistan and Iran" (2011). An interesting anecdote was provided to the author by a former Iranian foreign ministry official who spoke about the issues Tajik religious students faced when returning from their studies in Iran: "I was in Tajikistan in 2011, I saw a Sunni talib [student] from Qom, he was a Tajik. He said to me 'when I went to my village I was trying to do the same thing I learnt with my religion that I have learnt for four years, I was called an infidel from two talibs who had returned to my village from Pakistan. They said that I was a liberal and that I shouldn't be there. They said I was an infidel, so I had to flee my village, because I have been brought up in Qom with this mentality." Further to these comments, this former official disagreed that the ban on Tajik students studying Islam abroad was aimed at Iran. He felt that the Tajik government was forced to impose a blanket ban so as not to cause too much of a ruction in relations with individual states, such as Pakistan-a destination that many Tajiks who held "extremist" views had gone to undertake religious studies (Former Iranian Foreign Ministry Official, 2013). The view that this ban was also not aimed at Iran is also advanced in Nourzhanov $(2012$, p. 376).

${ }^{39}$ In a statement to the international media in 2012, Rahmon declared in the strongest terms his belief that Iran's nuclear program was indeed peaceful_- "According to our data, the Islamic Republic of Iran is not seeking to obtain or build a nuclear weapon. The Islamic Republic of Iran is on the path of progress, the country is developing. . All the issues, one way or another connected with the nuclear issue, should be resolved only through dialogue and diplomacy." See "Tajik president says" (2012).

${ }^{40}$ However, it is also interesting to note that there were rumors alluded to in the Wikileaks' cables that if there was a vote on the floor of the UN General Assembly in relation to Iran's nuclear program that Tajikistan would abstain from voting, which could be interpreted as a sign of Tajikistan's nonsupport of Iran's nuclear program after many years of consistently voting against numerous international resolutions against Iran, particularly in relation to alleged human rights violations. For discussion, see General Assembly of the United Nations (2014) and Hoagland (2006d).

${ }^{41}$ For a further discussion of Uzbek-Russian ties post-2005, see Trenin (2007, pp. 75-136).

\section{References}

Afghan government "cools" joint Iran-Tajik-Afghan TV project. (2010, April 21). BBC Monitoring Media. Retrieved from http://search.proquest.com/docview/452241361?accountid=8330; http: / / library.anu.edu.au:4550/resserv?genre=unknown\&issn =\&title $=$ BBC + Monitoring + Media\&volume $=\&$ issue $=\&$ date $=2010-04-21 \&$ atitle $=$ Afghan + government $+\% 22$ cools $\% 22+$ joint + Iran-Tajik-Afghan + TV + project\&spage $=$ \&aulast $=$ Anonymous\&sid $=$ ProQ:ProQ\%3Aanznews \&isbn $=\&$ title $=$ BBC + Monitoring + Media\&btitle $=\&$ \&id $=$ doi:.

Afghan-Iranian-Tajik TV project still in limbo. (2011). Radio Free Europe/Radio Liberty. Retrieved from http:/ /www.rferl.org/content/afghan_iran_tajik_tv_project/24180773.html.

Ahmadinejad says Iran, Tajikistan should guard interests of regional states. (2011, September 6). The Times of Central Asia. Retrieved from http://search.proquest.com/docview/887760934?accountid= 
8330;http:/ /library.anu.edu.au:4550/resserv?genre= unknown\&issn =\&title $=$ The + Times + of + Central + Asia\&volume $=\&$ issue $=\&$ date $=2011-09-06 \&$ atitle $=$ Ahmadinejad + says + Iran $\% 2 C+$ Tajikis$\tan +$ should + guard + interests + of + regional + states... $+\%$ BDerived + Headline $\% 5$ D\&spage $=$ \&aulast $=$ Anonymous\&sid $=$ ProQ:ProQ\%3Anewsstand\&isbn $=\&$ jitle $=$ The + Times + of + Central + Asia\&btitle $=\& i d=$ doi:.

Ahmadinejad says Tajik-Iranian cooperation serves peace in region. (2011, September 5). BBC Monitoring Newsfile. Retrieved from http://search.proquest.com/docview/887491859?accountid=8330; http:/ /library.anu.edu.au:4550/resserv?genre= unknown\&issn $=\&$ title $=$ BBC + Monitoring + Newsfile $\&$ volume $=$ \&issue $=\&$ date $=2011-09-05 \&$ atitle $=$ Ahmadinezhad + says + Tajik-Iranian + cooperation + serves + peace + in + region\&spage $=$ \&aulast $=$ Anonymous\&sid $=$ ProQ:ProQ $\% 3$ Aanznews\&isbn $=$ \&jtitle $=\mathrm{BBC}+$ Monitoring + Newsfile\&btitle $=\& \mathrm{id}=$ doi:

Ahmadinejad sees no limit to expansion of ties with Tajikistan. (2006, January 18). Tehran Times. Retrieved from http:/ / old.tehrantimes.com/Description.asp?Da=1/18/2006\&Cat=2\&Num=10.

Atai, Farhad. (2000). Iran and the newly independent states of Central Asia. In Ali Mohammadi \& Anoushiravan Ehteshami (Eds.), Iran and Eurasia (pp. 111-124). Reading: Garnet \& Ithaca Press.

Athary, Seyed Assadolah. (2001). Roundtable: Foreign policy of the Islamic Republic of Iran toward Central Asia and the Caucasus. Discourse: An Iranian Quarterly, 8, 1-42.

Atkin, Muriel. (2013). Iran, Russia and Tajikistan's civil war. In Stephanie Cronin (Ed.), IranianRussian encounters: Empires and revolutions since 1800 (pp. 361-376). London: Routledge.

Bahr Mabradar-ye az Faz 2 Neer va Gah Sangtudeh 2 Anjam Meeshavad [In Persian]. (2013). Retrieved from http:/ /www.iras.ir/vdcbw0b5.rhbz9piuur.html.

Berman, Ilan. (2004). The new battleground: Central Asia and the Caucasus. Washington Quarterly, 28(1), 59-69.

Blake, Robert O. (2013). Regional integration: Afghanistan. U.S. Department of State. Retrieved from http://www.state.gov/p/sca/rls/rmks/2012/187077.htm.

Bureau of European and Eurasian Affairs. (2002). U.S. government assistance to and cooperative activities with Eurasia. Washington, DC: U.S. Department of State.

Bureau of European and Eurasian Affairs. (2003). U.S. government assistance to and cooperative activities with Eurasia. Washington, DC:: U.S. Department of State.

Clark, Brenton. (2012). Iranian foreign policy towards Tajikistan and Afghanistan during the Ahmadinejad presidency: The rising salience of Persian national identity. Journal of Central Asian and Caucasian Studies, 7(13), 73-105.

Cordesman, Anthony H., Bosserman, Bradley, \& Khazai Sam. (2012). U.S. and Iranian strategic competition: The sanctions game: Energy, arms control, and regime change. A report of the CSIS Burke Chair in Strategy. Washington, DC: Center for Strategic and International Studies.

Daly, John C. K. (2007, August 10). Unlocking the hydroelectric potential of Tajikistan. UPI International. Retrieved from http://www.terradaily.com/reports/Unlocking_The_Hydroelectric_ Potential_Of_Tajikistan_999.html.

Dareini, Ali Akbar. (2010, March 27). Iran reach out to neighbors in new year summit. The Associated Press. Retrieved from http://www.afghanistannewscenter.com/news/2010/march/ mar282010.html\#7.

Djalili, Mohammed-Reza, \& Grare, Frederic. (1998). Regional ambitions and interests in Tajikistan: The role of Afghanistan, Pakistan and Iran. In Mohammed-Reza Djalili, Frederic Grare, \& Shirin Akiner (Eds.), Tajikistan: The trials of independence (pp. 119-131). Surrey: Curzon.

Dobbins, James. (2010). Engaging Iran. In Robin B. Wright (Ed.), The Iran primer: Power, politics, and U.S. policy (pp. 203-205). Washington, DC: United States Institute of Peace.

Dorraj, Manochehr, \& Entessar, Nader. (2013). Iran's northern exposure: Foreign policy challenges in Eurasia. Occasional Paper No. 13. Qatar: Center for International and Regional Studies, Georgetown University School of Foreign Service in Qatar.

Dunn, Ross. (1997, May 31). The winds of change start to blow through - Iran: Khatami's way. The Sydney Morning Herald, 27.

Envoy: Iranian companies implementing over 160 projects in Tajikistan. (2013, May 1). Asia News Monitor. Retrieved from http://search.proquest.com/docview/1346908760?accountid=8330; http: / / library.anu.edu.au:4550/resserv?genre=unknown\&issn=\&title=Asia +News + Monitor \&volume $=$ \&issue $=$ \&date $=2013-05-01 \&$ atitle $=$ Iran $\% 2$ FTajikistan $\% 3 \mathrm{~A}+$ Envoy $\% 3 \mathrm{~A}+$ Iranian + Companies + Implementing + over $+160+$ Projects + in + Tajikistan \&spage $=$ \&aulast $=\&$ sid $=$ ProQ: ProQ\%3Anewsstand\&isbn $=\&$ title $=$ Asia + News + Monitor\&btitle $=\& i d=$ doi:

Ergasheva, Zarina. (2014, January 16). Tajik electric power authorities do not know when Sangtuda-2 HPP will be reintroduced into operation. Asia Plus. Retrieved from http://news. $\mathrm{tj} / \mathrm{en} /$ news/tajik-electric-power-authorities-do-not-know-when-sangtuda-2-hpp-will-be-reintroduced-operation. 
Farab Energy and Water Projects. (2014). Field of activities: Hydropower projects. Retrieved from http:/ / www.farab.com/en/field_of_activities/prjlist.asp?abv $=\mathrm{H} \& \mathrm{tPk}=0$.

Farrar-Wellman, Ariel, \& Frasco, Robert. (2010). Tajikistan-Iran foreign relations. Iran Tracker. Retrieved from http://www.irantracker.org/foreign-relations/tajikistan-iran-foreign-relations.

FM: Iran-Tajikistan trade ties surpass $\$ 210 \mathrm{mln}$ in 2012. (2013, July 22). Asia News Monitor. Retrieved from http://search.proquest.com/docview/1403369064?accountid=8330; http:// library.anu.edu.au:4550/resserv?genre $=$ unknown\&issn $=$ \&title $=$ Asia + News + Monitor\&volume $=$ \&issue $=$ \&date $=2013-07-22 \&$ atitle $=$ Iran $\% 2$ FTajikistan $\% 3$ A + FM $\% 3 A+$ Iran-Tajikistan + Trade + Ties + Surpass $+\% 24210 \mathrm{mln}+\mathrm{in}+2012 \&$ spage $=$ \&aulast $=\&$ sid $=$ ProQ:ProQ\%3Anewsstand\&isbn $=\&$ ititle $=$ Asia + News + Monitor $\&$ btitle $=\& i d=$ doi:.

Former Iranian Ambassador. (2013, April 11). Recorded Interview with Author.

Former Iranian Foreign Ministry Official. (2013, April 28). Recorded Interview with Author.

Former State Advisor to the Tajik President. (2013, June 4). Recorded Interview with Author.

Former Tajik Government Official. (2013, June 1). Recorded Interview with Author.

Francois, Renaud. (2010). Central Asia: Between the breakdown of the CSTO and the emergence of Iran. ESISC Analysis, 1-5.

Freedman, Robert O. (2000). Russian-Iranian relations in the 1990s. Middle East Review of International Affairs, 4(2), 65-80.

General Assembly of the United Nations. (2014). Voting records. Retrieved from http://www.un. org/en/ga/documents/voting.asp.

Golovina, Maria. (2006, July 27). Iran seeks to gain influence in Central Asia. The Star. Retrieved from http: / / www.thestar.com.my/story /?file $=\% 2 \mathrm{f} 2006 \% 2 \mathrm{f} 7 \% 2 \mathrm{f} 27 \% 2$ fworldupdates $\% 2 \mathrm{f} 2006$ 07-27T034853Z_01_NOOTR_RTRJONC_0_-261165-1\&sec=worldupdates.

Habibi, Nader. (2013, June). The economic legacy of Mahmoud Ahmadinejad. Middle East Brief, $74,1-8$.

Hasanova, Mavjouda. (2009). Iran's exhibition promotes expansion of Tajik-Iranian cooperation, says Iranian envoy. Asia Plus. Retrieved from http://news.tj/en/news/iran-s-exhibition-promotes-expansion-tajik-iranian-cooperation-says-iranian-envoy.

Hoagland, Richard. (2006a). Ambassador's farewell call on Tajik FM Talbak Nazarov. Wikileaks. Retrieved from https://www.wikileaks.org/plusd/cables/06DUSHANBE1423_a.html.

Hoagland, Richard. (2006b). Iranian and Afghan presidents' visit to Dushanbe brings no surprises, just Persian brotherly love. Wikileaks. Retrieved from https://www.wikileaks.org/ plusd/cables/06DUSHANBE1435_a.html.

Hoagland, Richard. (2006c). Tajik hydropower 201: Advanced game theory. Wikileaks. Retrieved from https://www.wikileaks.org/plusd/cables/06DUSHANBE327_a.html.

Hoagland, Richard. (2006d). Tajikistan: Iran points delivered. Wikileaks. Retrieved from https:// www.wikileaks.org/plusd/cables/06DUSHANBE279_a.html.

Hoagland, Richard. (2006e). Tajikistan's Sharipov discusses corruption, Iran, Russia, hydro-power politics. Wikileaks. Retrieved from https://www.wikileaks.org/plusd/cables/06DUSHANBE779_a.html.

Hunter, Shireen. (2010). Iran's foreign policy in the post-Soviet era: Resisting the new international order. Santa Barbara, CA: Praeger.

Huntington, Samuel P. (1993). The clash of civilizations? Foreign Affairs, 72(3), 22-49.

Hussain, Nazir. (2002). Dialogue among civilizations in Asia and the world. The Iranian Journal of International Affairs, XIV(1 \& 2), 73-85.

Iji, Tetsuro. (2001). Multiparty mediation in Tajikistan: The 1997 peace agreement. International Negotiation, 6(3), 357-385.

Imam Khomeini Relief Committee. (2008/2009). Gozaresh-e Amari-ye 1387 [In Persian]. Retrieved from www.emdad.ir/gozareshat/files/s/1387/fasle19.pdf.

'International silence' on Tajikistan assailed. (1992, November 15). [FBIS-NES-92-227, Daily Report. Near East E South Asia, 1992, November 24], 62-63. Tehran: Keyhan.

Iran 5th biggest Tajik investor. (2013, January 30). Iran Daily. Retrieved from http://search.proquest. com/docview/1368132442?accountid=8330; http:/ / library.anu.edu.au:4550/ resserv?genre $=$ unknown\&issn $=15640205 \&$ title $=$ Iran + Daily\&volume $=\&$ issue $=\& d a t e=2013-01-30 \&$ atitle $=$ Iran +5 th + Biggest + Tajik + Investor\&spage $=\&$ aulast $=\&$ sid $=$ ProQ:ProQ $\% 3$ Anewsstand\&isbn $=$ \&jtitle $=$ Iran + Daily\&btitle $=$ \&id $=$ doi:.

Iran delaying Tajik-Afghan-Iranian TV channel Tajik official. (2011, January 14). BBC Monitoring Media. Retrieved from http://search.proquest.com/docview/839461289?accountid=8330; http: / / library.anu.edu.au:4550/resserv?genre =unknown\&issn=\&title =BBC +Monitoring + Media\&volume $=$ \&issue $=\&$ date $=2011-01-14$ \&atitle $=$ Iran + delaying + Tajik-Afghan-Iranian + $\mathrm{TV}+$ channel + Tajik + official\&spage $=$ \&aulast $=$ Anonymous\&sid $=$ ProQ:ProQ\%3Aanznews\&isbn $=\&$ title $=$ BBC + Monitoring + Media\&btitle $=\& i d=$ doi:.

Iran denies involvement in Tajik Mufti's death. (1996, January 23). [FBIS-NES-96-015, Daily Report. Near East E South Asia, 1996, January 23], 49-50. Tehran: IRNA. 
Iran: Middle East overshadows president's central Asia agenda. (2006). Radio Free Europe/Radio Liberty. Retrieved from http://www.rferl.org/content/article/1070105.html.

Iran, Tajikistan, Afghanistan to launch joint TV network. (2008, July 7). Tehran Times. Retrieved from http:/ / old.tehrantimes.com/index_View.asp?code=172539.

Iran, Tajikistan ink agreement on construction of more power plants. (2011, September 8). Asia News Monitor. Retrieved from http://search.proquest.com/docview/889162398?accountid =8330; http://library.anu.edu.au:4550/resserv?genre=unknown\&issn $=\&$ title $=$ Asia + News + Monitor\&volume $=$ \&issue $=$ \&date $=2011-09-08 \&$ atitle $=$ Iran $\% 2 F T a j i k i s t a n \% 3 \mathrm{~A}+$ Iran $\% 2 C+$ Tajikistan +Ink + Agreement + on + Construction + of + More + Power +Plants\&spage $=$ \&aulast $=$ \&sid=ProQ:ProQ\%3Anewsstand\&isbn=\&jtitle=Asia + News + Monitor\&btitle=\&id = doi:

Iran's Maleki on Expansion of Relations. (1992, January 11). [FBIS-SOV-92-009, Daily Report. Central Eurasia, 1992, January 14], 66-67. Tehran: IRNA.

Iranian Ambassador. (2013, May 4). Recorded Interview with Author.

Iranian Central Asian Foreign Policy Expert. (2013, April 5). Recorded Interview with Author.

Iranian company to complete tunnel in Tajikistan. (2013, April 10). BBC Monitoring Newsfile. Retrieved from http://search.proquest.com/docview/1324976428?accountid=8330; http:// library.anu.edu.au:4550/resserv?genre $=$ unknown\&issn $=\&$ title $=B B C+$ Monitoring + Newsfile \&volume $=$ \&issue $=\&$ date $=2013-04-10 \&$ atitle $=$ Iranian + company + to + complete + tunnel + in + Tajikistan\&spage $=\&$ aulast $=\&$ sid $=$ ProQ:ProQ $\% 3$ Aanznews \&isbn $=\& j$ title $=\mathrm{BBC}+$ Monitoring + Newsfile\&btitle $=\&$ id $=$ doi:.

Iranian president in tajik capital, warns of mideast 'storm.' (2006). Radio Free Europe/Radio Liberty. Retrieved from http://www.rferl.org/content/article/1070095.html.

Joharifard, Azadeh. (2008). Iran, Afghanistan, and Tajikistan alliance: Assessing the potential of a Persianspeaking association. Burnaby: Masters of Arts in International Studies, Simon Fraser University.

Jonson, Lena. (2006). Tajikistan in the new central Asia: Geopolitics, great power rivalry and radical Islam. London: IB Tauris.

Khudonazar, Davlat. (1995). The conflict in Tajikistan: Questions of regionalism. In Roald Z. Sagdeev \& Susan Eisenhower (Eds.), Central Asia: Conflict, resolution, and change (pp. 249-265). Chevy Chase: CPSS Press.

Kroth, Olivia. (2012). Russia, China, Iran close ranks in Tajikistan. Pravda. Retrieved from http:// english.pravda.ru/world/asia/30-10-2012/122620-russia_china_iran-0/.

Kucera, Joshua. (2011). Tajikistan invites Iranian military to intervene. Eurasianet. Retrieved from http://www.eurasianet.org/node/64221.

Kucera, Joshua. (2013a). Rouhani may go to Bishkek, but unlikely to focus on SCO. Eurasianet. Retrieved from http://www.eurasianet.org/node/67397.

Kucera, Joshua. (2013b). Tajikistan's folly? The Rogun dam. Pulitzer Center on Crisis Reporting. Retrieved from http://pulitzercenter.org/reporting/central-asia-tajikistan-rogun-vakhshriver-dam-impoverished-uzbekistan-worldbank-UN.

Lemon, Edward. (2010). Tajikistan: Dushanbe forcing students abroad to return home. Eurasianet. Retrieved from http://www.eurasianet.org/node/62460.

The Lengthening List of Iran Sanctions. (2013). Council on foreign relations. Retrieved from http:// www.cfr.org/iran/lengthening-list-iran-sanctions/p20258.

Mackenzie, Peter. (2010). A closer look at China-Iran relations. CNA China Studies Roundtable Report (Vol. 2). Washington, DC: CNA.

Mahmoudi, Morteza. (2009). Asia Markazi Va Roshd Hamkariha-ye Chand Janeb-e Iran va Tajikistan [In Persian]. Moassese Motaleat Iran va Eurosia. Retrieved from http://www.iras.ir/fa/ pages $/$ content.php?id $=608$.

Maleki, Abbas. (2007). Iran. In S. Frederick Starr (Ed.), The new silk roads: Transport and trade in greater Central Asia (pp. 167-192). Washington, DC: Johns Hopkins University Press.

Malekian, Mohsen. (2012). Roubat-e Farhang-e Iran va Tajikistan [In Persian]. Mowtalat Avar Asiaye Markazi, 11, 95-114.

Mannonov, Bahrom. (2006). Dushanbe mayor's office endorses design by Iranian architects for 25-story high rise. Asia Plus. Retrieved from http://www.news.tj/en/news/dushanbemayor-s-office-endorses-design-iranian-architects-25-story-high-rise.

Marat, Erica. (2007, March 21). Celebrating Novruz in Central Asia. Central Asia-Caucasus Analyst. Retrieved from http://old.cacianalyst.org/?q=node/4481.

Medrea, Sergey. (2008, April 2). Persian-speaking union created by Afghanistan, Iran, Tajikistan. Central Asia-Caucasus Analyst. Retrieved from http://old.cacianalyst.org/?q=node/4832.

Mesbahi, Mohiaddin. (1994). Iran and Tajikistan. In Alvin Z. Rubinstein \& Oles M. Smolansky (Eds.), Regional power rivalries in the New Eurasia: Russia, Turkey, and Iran (pp. 109-139). Armonk: M.E. Sharpe.

Mirsanjari, Mirmehrdad. (2010, January 24). The union of the Iranian Plateau. Tabnak Newws. Retrieved from http:/ / www.iranreview.org/content/Documents/The_Union_of_Iranian_Plateau.htm. 
Mullojonov, Parviz. (2001). The Islamic clergy in Tajikistan since the end of the Soviet period. In Stephane A. Dudoignon \& Komatsu Hisao (Eds.), Islam in politics in Russia and Central Asia (pp. 221-268). London: Kegan Paul.

Najibullah, Farangis. (2008). Iran pushes cross-border TV project. Radio Free Europe/Radio Liberty. Retrieved from http://www.rferl.org/content/article/1079698.html.

Najibullah, Farangis. (2009). Trip cancellation fuels rumors of rift in Tajik-Russian relations. Radio Free Europe/Radio Liberty. Retrieved from http://www.rferl.org/content/Trip_Cancellation_ Raises_Doubts_About_TajikRussian_Relations/1377978.html.

North Atlantic Treaty Organization. (2002). Tajikistan signs the Partnership for Peace Framework Document. Retrieved from http://www.nato.int/cps/en/natolive/news_19493.htm?selected Locale $=$ en.

Nourzhanov, Kirill. (2012). Omnibalancing in Tajikistan's foreign policy: Security-driven discourses of alignment with Iran. Journal of Balkan and Near Eastern Studies, 14(3), 363-381.

Nourzhanov, Kirill, \& Bleuer, Christian. (2013). Tajikistan: A political and social history. Canberra: The Australian National University E-Press.

Observatory of Economic Complexity. (2014). Tajikistan. Retrieved from http://atlas.media.mit. $\mathrm{edu} /$ profile/country/tjk/.

Pahlavi, Pierre, \& Hojati, Afshin. (2010). Iran and Central Asia: The smart politics of prudent pragmatism. In Emilian Kavalski (Ed.), The new Central Asia: The regional impact of international actors (pp. 215-238). Hackensack, NJ: World Scientific.

Persian-Language TV station to debut in Afghanistan, Iran, Tajikistan. (2010, February 4). Radio Free Europe/Radio Liberty. Retrieved from http://www.rferl.org/content/PersianLanguage_ TV_Station_To_Debut_In_Afghanistan_Iran_Tajikistan/1949102.html.

Peyrouse, Sébastien, \& Ibraimov, Sadykzhan. (2010). Iran's Central Asian temptations. Current Trends in Islamist Ideology, 10, 87-101.

Q\&A: Iran sanctions. (2013). Retrieved from http://www.bbc.co.uk/news/world-middle-east15983302

Robin, Allen. (1997, August 23). Peaceful evolutionist: Robin Allen on the challenges confronting Iran's president after his landslide election victory. Financial Times, 7.

Sanaei, Mehdi. (2011). Relations between Iran and Central Asia: Trends and prospects [In Persian]. Tehran: Institute for Political and International Studies.

Sariolghalem, Mahmood. (2000). Roundtable: Iran's foreign policy during khatami's presidency. Discourse: An Iranian Quarterly, 2(1), 1-38.

Shodon, Rasoul. (2011). Iran reportedly the largest investor in Tajikistan in 2010. Asia Plus. Retrieved from http://news.tj/en/news/iran-reportedly-largest-investor-tajikistan-2010.

Smith, Mark A. (2002). The Russo-Iranian relationship. Camberley: Conflict Studies Research Centre, Royal Military Academy Sandhurst.

Sodiqov, Alexander. (2011a). Iran builds closer ties with Tajikistan. Central Asia-Caucasus Analyst, 12(11), 19-20.

Sodiqov, Alexander. (2011b). Tajik-Iranian ties flourish. Jamestown Foundation Eurasia Daily Monitor, 8(72). Retrieved from http://www.jamestown.org/single/?no_cache=1\&tx_ttnews\%5Bs words\%5D=8fd5893941d69d0be3f378576261ae3e\&tx_ttnews\%5Bany_of_the_words\%5D=sodiqov \&tx_ttnews \%5Btt_news $\% 5 \mathrm{D}=37751 \& t x \_t$ tnews $\% 5 B b a c k P i d \% 5 D=7 \& c H a s h=97 a 1107 c 36 e 5 b 6 b 18 \mathrm{c}$ 5ff741402e6a75\#.VNohfJ2UeSo.

Sodiqov, Alexander. (2012). Iran's latest investment pledge raises questions in Tajikistan. The Central Asia-Caucasus Institute Analyst. Retrieved from http://www.cacianalyst.org/publications / field-reports/item/12463-field-reports-caci-analyst-2012-3-7-art-12463.html.

Tajik Air cancels flights to Tehran. (2012, October 11). Radio Free Europe/Radio Liberty. Retrieved from http:/ / www.rferl.org/content/tajikair-tehran-iran-tajiksitan-rial/24736442.html.

Tajik airline resumes weekly flights to Mashhad. (1998, October 13). BBC Monitoring Central Asia. Retrieved from http://search.proquest.com/docview/450722787?accountid=8330; http:// library.anu.edu.au:4550/resserv?genre $=$ unknown\&issn $=$ \&title $=\mathrm{BBC}+$ Monitoring + Central + Asia\&volume $=\&$ issue $=\&$ date $=1998-10-13 \&$ atitle $=$ Tajik + airline + resumes + weekly + flights + to +Mashhad\&spage $=1 \&$ aulast $=\&$ sid $=$ ProQ:ProQ $\% 3$ Anewsstand $\& i s b n=\& j t i t l e=B B C+$ Monitoring + Central + Asia\&btitle $=\& i d=$ doi: .

Tajik customs agents hold Iranian gear for joint TV project. (2012). Radio Free Europe/Radio Liberty. Retrieved from http://www.rferl.org/content/tajik-customs-agents-hold-iranian-gear-forjoint-tv-project/24707173.html.

Tajik leader praises cooperation with Iran. (2011, September 5). BBC Monitoring Newsfile. Retrieved from http:/ / search.proquest.com/docview/887485689?accountid=8330; http:/ / library.anu. edu.au:4550/resserv?genre $=$ unknown\&issn $=\&$ title $=$ BBC + Monitoring + Newsfile \&volume $=$ \&issue $=$ \&date $=2011-09-05 \&$ atitle $=$ Tajik + leader + praise + cooperation + with + Iran\&spage $=$ \&aulast $=$ Anonymous\&sid $=$ ProQ:ProQ\%3Aanznews\&isbn $=$ \&jtitle $=$ BBC + Monitoring + Newsfile \&btitle $=\&$ id $=$ doi:. 
Tajik leader upbeat on cooperation with Iran. (2010, January 4). BBC Monitoring Newsfile. Retrieved from http://search.proquest.com/docview/452350534?accountid=8330; http:/ / library.anu. edu.au:4550/resserv?genre $=$ unknown\&issn $=$ \&title $=B B C+$ Monitoring + Newsfile\&volume $=$ \&issue $=$ \&date $=2010-01-04 \&$ atitle $=$ Tajik + leader + upbeat + on + cooperation + with + Iran\&spage $=$ \&aulast $=$ Anonymous\&sid $=$ ProQ:ProQ $\% 3$ Aanznews\&isbn $=\& j$ title $=$ BBC + Monitoring + Newsfile\&btitle $=\& i d=$ doi:.

Tajik International Relations Scholar. (2013, May 20). Recorded Interview with Author.

Tajik parliament speaker opposes sanctions on Iran. (2012). Press TV. Retrieved from http:// www.presstv.com/detail/230767.html.

Tajik president meets visiting Iranian foreign minister. (2008, March 24). BBC Monitoring Nezwsfile. Retrieved from http://search.proquest.com/docview/452373558?accountid=8330; http:// library.anu.edu.au:4550/resserv?genre $=$ unknown\&issn $=\&$ title $=B B C+$ Monitoring + Newsfile\&volume $=$ \&issue $=$ \&date $=2008-03-24$ \&atitle $=$ Tajik + president + meets + visiting + Iranian + foreign + minister\&spage $=$ \&aulast $=$ Anonymous\&sid $=$ ProQ:ProQ $\%$ 3Aanznews\&isbn $=\& j$ title $=\mathrm{BBC}+$ Monitoring + Newsfile\&btitle $=\& \mathrm{id}=\mathrm{doi}:$

Tajik president says his country suffering from sanctions against Iran. (2012, March 31). BBC Monitoring Newsfile. Retrieved from http://search.proquest.com/docview/963307820?accountid=8330; http:/ / library.anu.edu.au:4550/resserv?genre =unknown\&issn = \&title $=$ BBC + Monitoring + Newsfile \&volume $=\&$ issue $=\&$ date $=2012-03-31 \&$ atitle $=$ Tajik + president + says + his + country + suffering + from + sanctions + against + Iran\&spage $=$ \&aulast $=\&$ sid $=$ ProQ:ProQ $\% 3$ Aanznew$\mathrm{s} \& \mathrm{isbn}=\& \mathrm{title}=\mathrm{BBC}+$ Monitoring + Newsfile\&btitle $=\& \mathrm{id}=$ doi:.

Tajikistan and Iran: Is Dushanbe distancing itself from cultural cousin? (2011). Eurasianet. Retrieved from http://www.eurasianet.org/node/63021.

Tajikistan backs Iran's "peaceful" nuclear programme - leader. (2010, January 4). BBC Monitoring Newsfile. Retrieved from http://search.proquest.com/docview/452350271?accountid=8330; http:/ / library.anu.edu.au:4550/ resserv?genre=unknown\&issn =\&title $=$ BBC + Monitoring + Newsfile\&volume $=\&$ issue $=\&$ date $=2010-01-04 \&$ atitle $=$ Tajikistan + backs + Iran $\% 27 \mathrm{~s}+\% 22$ peaceful $\% 22+$ nuclear + programme +-+ leader\&spage $=$ \&aulast $=$ Anonymous\&sid $=$ ProQ: ProQ\%3Aanznews\&isbn $=\&$ jtitle $=\mathrm{BBC}+$ Monitoring + Newsfile\&btitle $=\& i d=$ doi:.

Tajikistan: Iran to the rescue. (2009, February 5). Eurasianet. Retrieved from http://www.eurasianet.org/departments/news/articles/eav020609b.shtml.

Tajikistan Ministry of Foreign Affairs. (2011). Tajikistan's hydro power potential. Dushanbe: Tajikistan Ministry of Foreign Affairs.

Tajikistan supports Iran's nuclear program - president. (2010). RIA Novosti. Retrieved from http:/ / en.ria.ru/world/20100104/157463639.html.

Tajikistan to cooperate with U.S. fight on terror. (2001, September 22). USA Today. Retrieved from http:/ / usatoday30.usatoday.com/news/nation/2001/09/22/tajikistan.htm.

Tajikistan: Where Iranian money takes a bath? (2013, August 21). Eurasianet. Retrieved from http://www.eurasianet.org/node/67417.

Trenin, Dmitri. (2007). Russia and Central Asia: Interests, policies, and prospects. In Eugene Rumer, Dmitri Trenin, \& Huasheng Zhao (Eds.), Central Asia: Views from Washington, Moscow and Beijing (pp. 75-136). Armonk: M.E. Sharpe.

Trilling, David. (2007). Tajikistan: The tunnel of fear. Eurasianet. Retrieved from http://www.eurasianet.org/departments/insight/articles/eav100207.shtml.

Trilling, David. (2012). Tajikistan: Q\&A with Iran's envoy to Dushanbe. Eurasianet. Retrieved from http:/ / www.eurasianet.org/node/65257.

Trilling, David. (2014, January 9). Tajikistan: Another hydropower debt dispute rattles industry. Eurasianet. Retrieved from http://www.eurasianet.org/node/67924.

Umarov, Khojamakhmad. (2007). Tajikistan. In S. Frederick Starr (Ed.), The new silk roads: Transport and trade in greater Central Asia (pp. 107-140). Washington, DC: Johns Hopkins University Press.

United Nations Comtrade. (2014). United Nations commodity trade statistics database. United Nations Statistics Division. Retrieved from http://comtrade.un.org/.

US Embassy. (2008). Tajikistan's ties to Iran deepening; Early stages of Persian axis? Wikileaks. Retrieved from https://www.wikileaks.org/plusd/cables/08DUSHANBE752_a.html.

US Embassy. (2009). Iran's role in Tajikistan: Limited but increasing? Wikileaks. Retrieved from http:/ / www.scoop.co.nz/stories/WL0908/S00646.htm.

Uzbek and Iranian presidents give news conference. (2002, April 27). BBC Monitoring Central Asia, 1. Retrieved from http://search.proquest.com/docview/450559150?accountid=8330; http:// library.anu.edu.au:4550/resserv?genre $=$ unknown\&issn $=\&$ title $=\mathrm{BBC}+$ Monitoring + Central + Asia\&volume $=$ \&issue $=$ \&date $=2002-04-27 \&$ atitle $=\% 28$ CORR $\% 29+$ Uzbek + and + Iranian + presidents + give + news + conference \&spage $=1 \&$ aulast $=\&$ sid $=$ ProQ:ProQ\%3Anewsstand \&isbn $=\&$ title $=\mathrm{BBC}+$ Monitoring + Central + Asia\&btitle $=\& i d=$ doi: 
Vakil, Sanam. (2006). Iran: Balancing east against west. The Washington Quarterly, 29(4), 51-65.

Vinson, Mark. (2012a). Ambitious Iranian-Tajik projects fact problems of geography and sanctions. Jamestown Foundation Eurasia Daily Monitor, 9(109). Retrieved from http://www.jamestown.org/single/?tx_ttnews\%5Btt_news\%5D=39482\&no_cache=1\#.VNohyp2UeSo.

Vinson, Mark. (2012b). Iranian soft power in Tajikistan: Beyond cultural and economic ties. Jamestown Foundation Eurasia Daily Monitor, 9(52). Retrieved from http://www.jamestown.org/single/?tx_ttnews\%5Btt_news\%5D=39133\&no_cache=1\#.VNohzZ2UeSo.

Zakaria, Fareed. (2012, January 4). Iran's growing state of desperation. The Washington Post. 